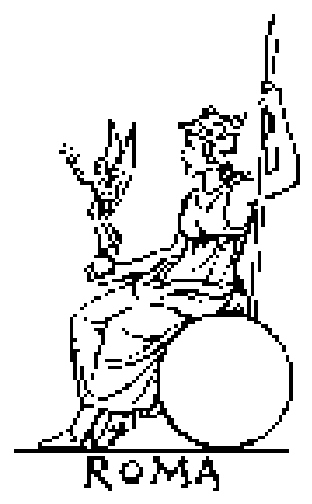

'Gnosticism' in Fourth-Century Britain: The Frampton Mosaics Reconsidered Author(s): Dominic Perring

Reviewed work(s):

Source: Britannia, Vol. 34 (2003), pp. 97-127

Published by: Society for the Promotion of Roman Studies

Stable URL: http://www.jstor.org/stable/3558541

Accessed: 28/11/2012 11:38

Your use of the JSTOR archive indicates your acceptance of the Terms \& Conditions of Use, available at http://www.jstor.org/page/info/about/policies/terms.jsp

JSTOR is a not-for-profit service that helps scholars, researchers, and students discover, use, and build upon a wide range of content in a trusted digital archive. We use information technology and tools to increase productivity and facilitate new forms of scholarship. For more information about JSTOR, please contact support@ jstor.org. 


\title{
'Gnosticism' in Fourth-Century Britain: the Frampton Mosaics Reconsidered
}

\author{
By DOMINIC PERRING
}

\section{INTRODUCTION}

$\mathrm{R}$ ecent years have seen a renewed interest in the significance of the mosaic designs employed in Roman houses. ${ }^{1}$ Studies have concentrated on establishing the mythological sources of the images chosen, and on describing the social and architectural contexts within which such art was used. ${ }^{2}$ It has long been noted that some of the subjects preferred in fourth-century Britain suggest allegorical references to the hereafter, ${ }^{3}$ although it has also been observed that the 'search for profound and coherent allegories may exaggerate the significance which the wealthy British patrons imparted to the floors of the great halls or dining-rooms of their villas'. ${ }^{4}$ Ling, in particular, has cautioned against reading exaggerated meanings into ambivalent images that may simply have been chosen to vaunt erudite taste. ${ }^{5}$

The various images, symbols, and signs used in Roman art were, however, exploited to display cultural status and affiliation: they spoke of the élite values (Latin otium and Greek paideia) that sustained Roman social life. ${ }^{6}$ Late antique sources witness the close engagement of the educated classes in the sophisticated philosophical arguments of the day. ${ }^{7}$ These arguments involved a detailed reading of history, allegory, and myth. The ideas at issue were commonly expressed in both words and pictures. Indeed one of the chief purposes of domestic art was to provide an appropriate setting for philosophical discussions and the intellectual theatre of poetry and literature. ${ }^{8}$ Art and iconography consciously spoke of and to an elevated scholarship. Archaeological readings of the evidence must necessarily engage with such arguments.

1 Several studies have proposed reconstructions of social arrangements from the evidence of mosaics and wall-paintings e.g. Wallace-Hadrill 1988. These decorative schemes offer clues as to paths of access and the relative status of the different parts of the house, although it has not generally been possible to draw a direct relationship between the character of the decoration and the function of the room (e.g. Tybout 2001; Muth 1998).

2 This has been a particular feature of Romano-British studies. For a review of research in this field see Ling 1997. Recent studies include those of Scott 2000 and Witts 2001. The short papers and notes published annually in the journal Mosaic also include several important contributions to this debate.

3 Toynbee 1964a.

4 Dunbabin 1999, 95.

5 Ling 1997.

6 Brown 1992.

7 Rossiter 1991.

8 Decorations were commonly most ambitious in peristyles and dining-rooms. According to Dickmann 1997, the Roman peristyle took inspiration from the architecture of the Greek gymnasium, providing a setting for the ambulatio with its attendant intellectual discourse. Similarly, the lavishly decorated dining-halls provided a setting for the entertainments that accompanied the rituals of symposium or convivium (Jones 1991; Slofstra 1995). The emphasis given to these facilities in the grander houses of Late Antiquity might reflect on Neoplatonic ideas then current. Learned guests would have recognised a contrast between the 'rational' argument of the gymnasium and the 'irrational' discourse of the wine-lubricated symposium (Teçusan 1990). The Platonic soul was a synthesis of these rational and irrational elements, and an educated understanding of this aspect of the human condition may have been acknowledged in social and architectural affectation. 
In this paper I concentrate on the evidence of a single pavement: a fourth-century floor found near Frampton in Dorset. This find has already been the subject of several previous studies inspired by its striking combination of pagan and Christian elements. ${ }^{9}$ The suggestion that I wish to make here is that these images were contrived to make a series of allegorical statements about the nature and destiny of the mortal soul, drawing intelligently on ideas that can best be described as Gnostic $^{10}$ and Orphic. ${ }^{11}$

These ideas are complicated, and cannot be given full justice in a brief paper such as this. Since, however, my argument assumes some understanding of the cosmographies involved, these demand brief introduction. ${ }^{12}$ Orphism was a mystery religion of ancient Greece, derived in part from the worship of Dionysus, that recognised the existence of a supreme being. Gnosticism was a religious movement characterised by a belief that the knowledge of spiritual truths, or gnosis, made it possible for man to escape the prison of mortal flesh and become one with God. The dualistic beliefs that characterised both Orphic and Gnostic worship were based on the idea that the human spirit was a spark of the divine trapped in the hostile matter of mundane existence. This imprisonment was the consequence of an act of creation in which the god that had made the known universe was himself the product of earlier acts of creation emanating from the Supreme Being. This god of mortal creation, known as the demiurge in Platonic and Gnostic philosophy, was not necessarily a benign power. Ritual worship was concerned with the revelation of the secrets that illuminated a path to redemption and salvation involving an escape from mortal matter. These are subjects that I will return to in somewhat more detail after first describing the archaeological evidence from which my conclusions are drawn.

In this paper I furthermore suggest that these allegorical statements about the nature of the human soul were used to create a space that could be used for the celebration of the Eucharist, in an elaboration of the domestic rituals of Roman dining practice.

In addition to the iconography of the pavements at Frampton, there are several other strands of evidence that can be used to support these suggestions. Important sources of evidence include the iconography of pavements from other Romano-British sites, the architecture of the buildings within which they were housed, and the decoration of silverware found in late hoards. These other sources, which will be described in a little more detail below, imply that the people who commissioned the pavements at Frampton were not alone in their concerns and beliefs. The evidence suggests a heterodoxy of Christian belief in fourth-century Roman Britain.

My conclusion, that we can recognise Gnostic and other ideas from the evidence of mosaics, has a series of implications that go far beyond the particular subject of this paper. In the first place it allows us to make more ambitious use of such archaeological evidence in the study of the diffusion and evolution of late antique ideologies. Regional diversity in the nature of the images deployed in private houses reflects emerging differences in the cosmographies favoured by élite society. There

9 As Toynbee 1968, Huskinson 1974, Black 1986, Henig 1986a, and Scott 2000.

10 Here Ihave followed common practice in describing as Gnostic the disparate schools of dualistic Christianity that were a principal target of the anti-heretical writings of Christian orthodoxy in Late Antiquity. Williams 1999 has described a series of problems with the use of this term, which is essentially the product of modern scholarship, and prefers the more neutral 'biblical demiurgical tradition'. Whilst accepting the validity of his argument, I have not felt it necessary to adopt his terminology.

11 Orphic and Gnostic influences in Romano-British mosaics have previously been proposed by Stupperich 1980, 300, Thomas 1981, 104-5, and Walters 1982 and 1984. The full implications of this suggestion have not, however, been appreciated in recent work on Christianity in Roman Britain.

12 Gnostic beliefs are described in various anti-heretical writings. Those of Irenaeus and Hippolytus are the most relevant to the reading of the Romano-British evidence; for these and other relevant texts see Roberts and Donaldson 1950-1957. Further detail is found in the cache of Gnostic tractates discovered at Nag Hammadi in Egypt in 1945, for which see Meyer and Robinson 1981. Important studies, in an increasingly active field, include those of Jonas 1958, Pagels 1979, Rudolph 1983, and Williams 1996. See also note 37 on the Orphic contribution to Gnostic ideas. 
is also scope to establish a better dialogue between the evidence of text and image in the study of belief systems.

One feature suggested by the Romano-British evidence is a surprisingly close affinity between Orphic-Bacchic and Christian-Gnostic ideas, illustrating some very Hellenised interpretations of the Christian message. Furthermore, the archaeological identification of diverging provincial approaches to the interpretation of Christianity has an important bearing on the political developments of the time. Any declaration and suppression of heretical belief in fourth-century Britain is likely to have taken a heavy toll on the coherence of élite society. There is a distinct possibility that theological arguments played a part in the processes that separated Britain from Rome.

Before expanding on these arguments, it is first necessary to turn to the evidence on which they can be built. The first part of this paper will, therefore, offer a detailed description of the Frampton mosaics, supported by some suggestions as to the iconographic significance of the images employed.

\section{THE FRAMPTON MOSAICS}

The mosaics near Frampton were first uncovered and drawn in April 1794. ${ }^{13}$ Samuel Lysons undertook more extensive excavations in 1796. In both cases the investigations were exclusively concerned with rooms containing mosaic pavements and no other archaeological remains were recorded. ${ }^{14}$ More recent attempts to study the site have added little to our understanding of its archaeology. According to a letter written in 1924 investigations that took place in 1903 failed to find any surviving traces of the mosaics. ${ }^{15}$ Local tradition encouraged the conclusion that the pavements had been destroyed by troops that had passed through the district on their way to Plymouth in 1854-5. Subsequent exploratory works have revealed additional traces of wall foundations, and suggest that the site is not entirely destroyed, but the results of these investigations were poorly documented and add little information. ${ }^{16}$ As a consequence the discussion that follows relies almost exclusively on the handsome coloured drawings published by Lysons, and we are fortunate in the accuracy of his draughtsmanship (as confirmed by the precision of his recording of other mosaic floors which have survived).

The mosaics were executed in a lively and confident schematic style, using a palette of four colours (red, black, blue, and yellow) against a white background, with some outer borders executed in buff. There were no significant stylistic differences between the various pavements found at this site and it is likely that they were all laid at the same time.

The site where the mosaics were found lies about $9 \mathrm{~km}(51 / 2 \mathrm{miles})$ north-west of the Roman town at Dorchester (Durnovaria), on an artificial terrace above water meadows overlooking a bend of the river Frome. Despite speculation that this may have been some form of cult site, based chiefly on the lack of evidence for subsidiary buildings and in part on its unusually low-lying location, the configuration of remains recorded by Lysons suggests that this was a villa set out over at least two principal ranges.

The main wing of the house was set behind an east-facing portico, represented by a corridor mosaic with a geometric pattern (FIG. 1). A figurative panel within this corridor, of which only the guilloche border survived, marked the position of a central doorway. This was probably the main entrance to the house. Rooms with mosaics were set at the opposite ends of this portico-corridor. The room at the northern end of the house projected forward of the line of the portico. This was a

\footnotetext{
Henig 1984.

Lysons 1817.

RIB 2448.8.

Farrar 1956.
} 


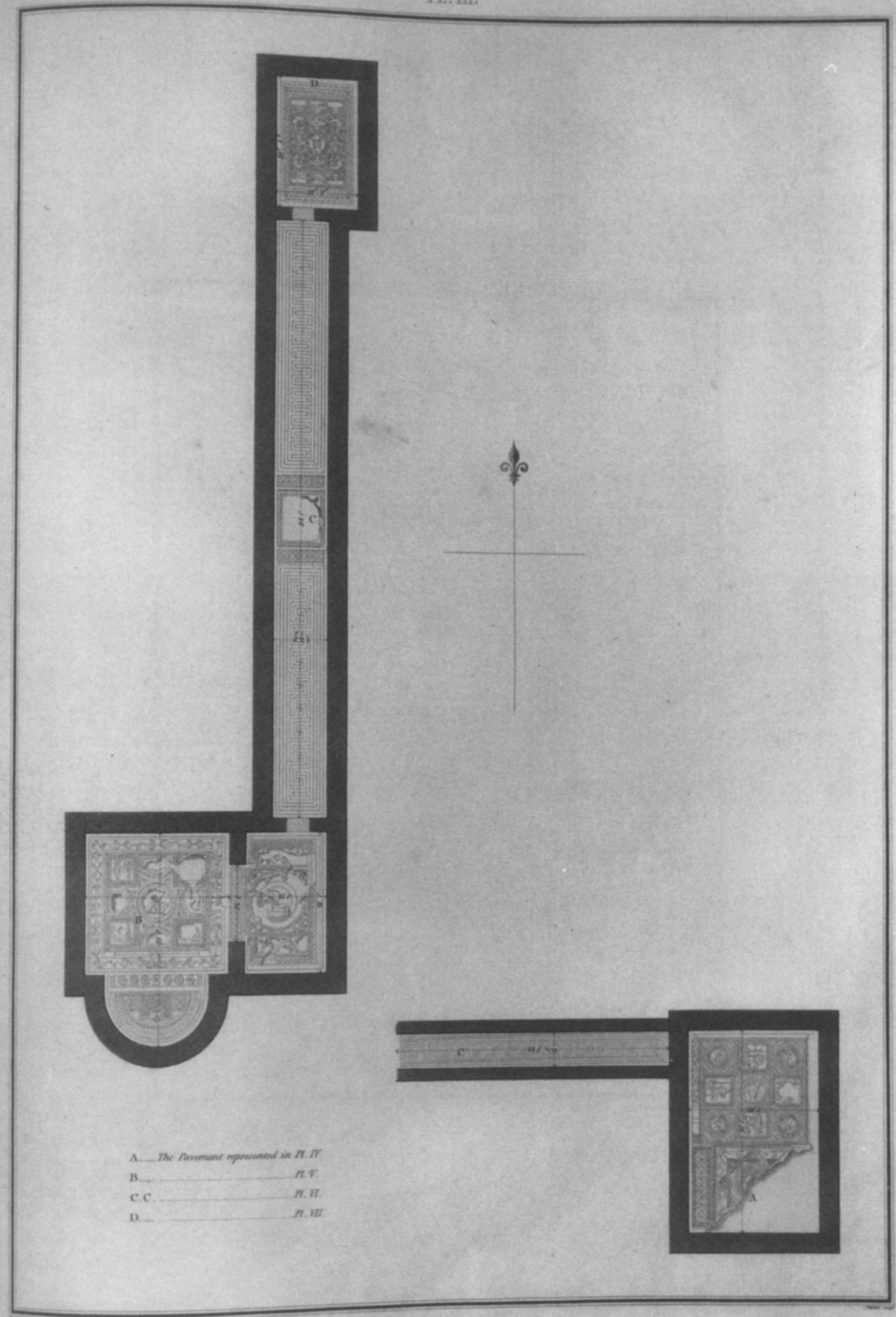

Ilan of the Mesaic Parroments discovernd nat Framplon in Derselsbine

FIG. 1. The location of the Frampton mosaics (from a coloured engraving by S. Lysons). 
small projecting 'wing', or corner pavilion, of a type common in Romano-British villas. ${ }^{17}$ The room was decorated to an aquatic theme, featuring Neptune.

The most lavishly decorated room within the house, and the main subject of this paper, was at the southern end of the portico. Such 'end rooms' are also a common feature of Romano-British houses. ${ }^{18}$ This room was divided into three parts: an antechamber 6.4 by $\left.4.58 \mathrm{~m} \mathrm{(21} \mathrm{by} 15 \mathrm{ft}\right)$ which featured a mosaic of Bacchus; a main room $6.4 \mathrm{~m}(21 \mathrm{ft})$ square with a central panel showing Bellerophon and a series of lesser panels with mythological scenes; and an apse $3.05 \mathrm{~m}(10 \mathrm{ft})$ deep which featured a chi-rho and cantharus (a two-handled crater or chalice).

Two more mosaics, showing Bacchus and Venus, were found within a bipartite room in a separate wing of the house to the south-east. This too had been approached by means of a corridor-portico, the floor of which had been decorated with a black and white geometrical pattern.

These pavements belong to a regional tradition of mosaics common to a number of villas in the area around Dorchester. Mosaics in this group were characterised by mythological and hunting scenes and shared some common approaches to the treatment of decorative detail. ${ }^{19}$ The closest parallels to the Frampton mosaics are found at Hinton St Mary. ${ }^{20}$ Several elements of the overall layout, the design of the borders, and the treatment of foliage and ivy-leaf scrolls are so similar that there can be little doubt that the same craftsmen were engaged on both projects. The floors at Hinton St Mary also drew on a very similar range of pagan and Christian motifs, where the main focus of the pavement was provided by the bust of a beardless male figure identified as Christ by the chi-rho nimbus behind his head. ${ }^{21}$

These designs were almost certainly executed around the middle of the fourth century (or were improbably faithful copies of originals designed in this period). Although no independent dating evidence was obtained from the investigations at Frampton, two features can be used to suggest a date for the pavement at Hinton St Mary. The figure of Christ has a hairstyle closely paralleled in the coinage of the earlier part of the reign of Constantius II, and Reece has argued that the model for this can be dated within a period ten years either side of A.D. $345 .{ }^{22}$ The chi-rho nimbus is, however, not otherwise attested before the late fourth century. It has consequently been argued that the mosaic can hardly be earlier than the third quarter of that century. ${ }^{23}$ On balance, therefore, this image can be described as a product of the period $c$. A.D. 350/355 or very shortly thereafter. This is consistent with the archaeological dating obtained from some other pavements in the same stylistic group. For instance the floors at Dewlish have a terminus post quem, derived from coin dating, of A.D. 353-356. ${ }^{24}$

\section{PAGAN AND CHRISTIAN ELEMENTS}

The pavements at Hinton St Mary and Frampton have diversely been interpreted as illustrating the

17 Perring 2002, 73-4; Smith, J.T. 1997, 117-29.

18 Perring 2002, 164.

19 Following the work of David Smith 1969 this is known as the 'Durnovarian School' (see also Johnson 1983). There is little doubt that similar ideas, arrangements, and motifs were shared by the villas near Dorchester (e.g. also at Wynford, Fifehead Neville, and Dewlish — for which see Scott 2000, 50), although the similarities between the mosaics may reflect on networks of élite patronage and shared values systems rather than on the operation of workshops (officinae) within a commercial market.

20 The excavations here were chiefly concerned with lifting the main mosaic panel now on display in the British Museum. Painter 1967 also describes the survival of other fragmentary foundations and mosaics, which suggest the presence of a winged building.

$21 \quad$ RIB 2448.14; Toynbee 1964b.

22 Reece 1980.

23 Brandenburg 1969.

24 Scott 2000, 50. 
Christianisation of pagan subjects, ${ }^{25}$ or the essential paganism of a lightly held Christianity. ${ }^{26}$ In the former view the 'Christian floors can hardly have belonged to anything but chapels or house churches', in the latter 'the chi-rho may have been chosen simply because it was the Emperor's standard and therefore a powerful amulet'. In either case the prominence given to a Christian symbol in such a pagan setting might, at first appearance, suggest a lack of intellectual coherence.

There were, of course, many other instances where pagan and Christian images were similarly juxtaposed. This was particularly the case with elements drawn from Orphic-Bacchic iconography, and some of the evidence for this will be discussed further below. The Christian interpretation of pagan figures reflected a general tendency within late antique art to draw on images received from earlier classical antiquity and give them fresh meanings by deploying them in new contexts and combinations. ${ }^{27}$ Syncretism had in any case characterised earlier religious developments, and was evident in the approach to Christianity adopted by its first imperial patrons. ${ }^{28}$ Notwithstanding such evidence, it remains the case that the Frampton images do not sit comfortably with fourthcentury Christian orthodoxy. Dunbabin makes the telling point that the references to Neptune and Cupid would not normally have been acceptable in a Christian cult building. ${ }^{29}$ She observes that the Hinton St Mary and Frampton mosaics demonstrate a symbiosis of pagan and Christian elements that might cover a multitude of personal interpretations, and concludes that the debate over their significance is unlikely to be settled.

This is perhaps true, but only up to a point. It is fair to say that a full reading of the meaning of these mosaics will always depend on a degree of speculation, but such readings can usefully be informed by late antique texts. These sources establish a context for the appreciation of this art: an intellectual framework that gave meaning to the iconographic vocabulary deployed. For instance the anti-heretical writings of early Christian sources and the philosophical contemplations of their contemporaries describe at length how some Christian heretics exploited pagan ideas and images in building their cosmographic interpretations. ${ }^{30}$ The allegorical mosaics found throughout the Roman world were undoubtedly intended to represent ideas, and this was a period when most ideas were framed in theological terms. ${ }^{31}$ The allegorical interpretation of mythological texts was firmly rooted in the Greek philosophy of Late Antiquity and a particular feature of Neoplatonist thinking. ${ }^{32}$ Philo of Alexandria has been credited with bringing such approaches into the service of religion in the course of the first century. ${ }^{33}$ The system of scriptural allegory evolved in his school subsequently served as a model for the first Christian fathers.

These writings, and the established symbolism of pagan mythology, provide a context for the elucidation of some of the ideas that influenced the design of late antique pavements. Eloquent classical images, even from such a remote corner of empire as the Dorset countryside, are more

\footnotetext{
Black 1986, 150.

Henig 1995, 154-6.

Elsner 1998, 219-25; Henig 1977a.

Chuvin 1990, 28.

Dunbabin 1999, 95-6. This view builds on earlier studies by Brandenburg 1968 and Huskinson 1974, which see the Christian motifs at Hinton St Mary and Frampton as intrusive within an otherwise pagan setting. Brandenburg 1969 argues that the use of the chi-rho here was merely apotropaic and need not imply any detailed engagement with the Christian message. This presupposes an improbable level of indifference to the heated arguments that animated the relationship between pagan and Christian elsewhere within the Roman world, for which see Chuvin 1990.

30 Such sources include the writings of Plotinus, Origen, Clement of Alexandria, Irenaeus, Hippolytus, Theodoret, and Epiphanius (Roberts and Donaldson 1950-1957). According to the 'Gnostic' Gospel of Philip, 'truth did not come into the world naked, but it came in types and images' (Nag Hammadi Codex II 3, 86; the translation is that offered by Rudolph

31 Elsner 1998, 223.

32 Perhaps here we see the origins of 'the detestable medieval habit of extracting a moral lesson from every fact or work of

33 Jonas 1958, 91.
} 1983, 246). art' (Highet 1957). 
likely to have been embedded within the discourse of the period than an aberrant invention of local perversity. It should be remembered that most of the figurative mosaics of this period were laid in long-established aristocratic houses, and it is therefore improbable that we are dealing with some rustic or parvenu failure of understanding that deprived the images of meaning. ${ }^{34}$ The complex choices of subject matter found in mosaics can be seen as the product of a deliberate and informed choice. ${ }^{35}$

If life after death is the subject, then we should assume that the treatment of the subject followed the particular belief systems and cosmological understandings of those who commissioned the work. The exercise of an eclectic approach to the use of iconography does not imply that the individual components were somehow less well understood or more casually deployed. It serves as a reminder of the richness of the allegorical vocabulary available at the time. The existence of this larger vocabulary is itself a token of the complexity of the concepts being expressed, and this adds to the burden of meaning that we can expect to find carried by iconographic choice.

If the mosaics at Frampton reflected on a coherent and informed understanding of the religious ideas of the day, and represented a decided position with regard to the relationship between Christian and pagan philosophies, then they are unlikely to have escaped the influence of Gnostic arguments. Several schools of Gnostic Christians were known to draw on pagan themes and images in presenting their ideas. Indeed one of the chief purposes of the anti-heretical writings of Hippolytus was to show how the different Gnostic sects had based their speculations on heathen philosophies and tolerated the worship of heathen gods, and at several points he describes how pagan themes were pressed into service as Gnostic allegories. ${ }^{36}$ Modern scholarship has illustrated how this partisan account fails to grasp the complexity of the origins of Gnostic thought, but the ancient sources suggest a context in which it would have been perfectly sensible and entirely coherent to present images of Bellerophon and Bacchus alongside the symbols of Christ. There are several other features of the Frampton pavements that lend support to this hypothesis. These include both the emphasis on Orphic-Bacchic themes and the dualistic nature of the arguments expressed. ${ }^{37}$ Evidence for this can be obtained by looking in closer detail at the significance and structure of the mosaics themselves and this, therefore, is where our attention must now turn.

\section{ICONOGRAPHIC READINGS}

The most elaborate and informative of the Frampton mosaics were those found within the larger tri-partite room at the southern end of the main portico-corridor (FIG. 2). The arrangement of space

34 Henig 2002, 78 summarises the evidence for Romano-British learning.

35 Mosaics required an exceptional level of investment. Even a comparatively small pavement from Colchester is estimated to have taken 700 man-hours to lay (Crummy 1980, 8; Perring 2002,132). This is not a situation in which choices would have been made in ignorant haste, or where the decorations would have been used out of context.

36 e.g. Hippolytus, Refutation of all Heresies 5.2 .

37 According to Hippolytus, Refutation of all Heresies 5.15, one Gnostic heresy, the Ophite doctrine, was inspired by the theology of Musaeus, Linus, and Orpheus. For the Orphic contribution to the development of Gnostic ideas see Legge 1964 and Guthrie 1966. Although this paper is primarily concerned with the evidence from Roman Britain, there is a much broader body of archaeological data that illustrates the use of Bacchic-Orphic themes within Christian contexts (Guthrie 1966, 253-5; Eisler 1925; Friedman 2000). Examples include the Roman Catacombs, where Bacchic masks and figures and masks of Oceanus also occur (de Rossi 1867, pl. 4, fig. 1). These belief systems may have contributed to documented instances of Christ being worshipped alongside Orpheus or Bacchus. Famous instances of this include the case of the emperor Alexander Severus who is said to have worshipped before the statues of Apollonios of Tyana, Christ, Abraham, and Orpheus in his private chapel (Hist. Aug., Sev Alex. 39.31), and that of the Christian poet Ausonius who also admitted the worship of Bacchus. Bowersock 1990, 41-53, describes further evidence for the introduction of Christian motifs and themes into Bacchic/Dionysiac contexts. 


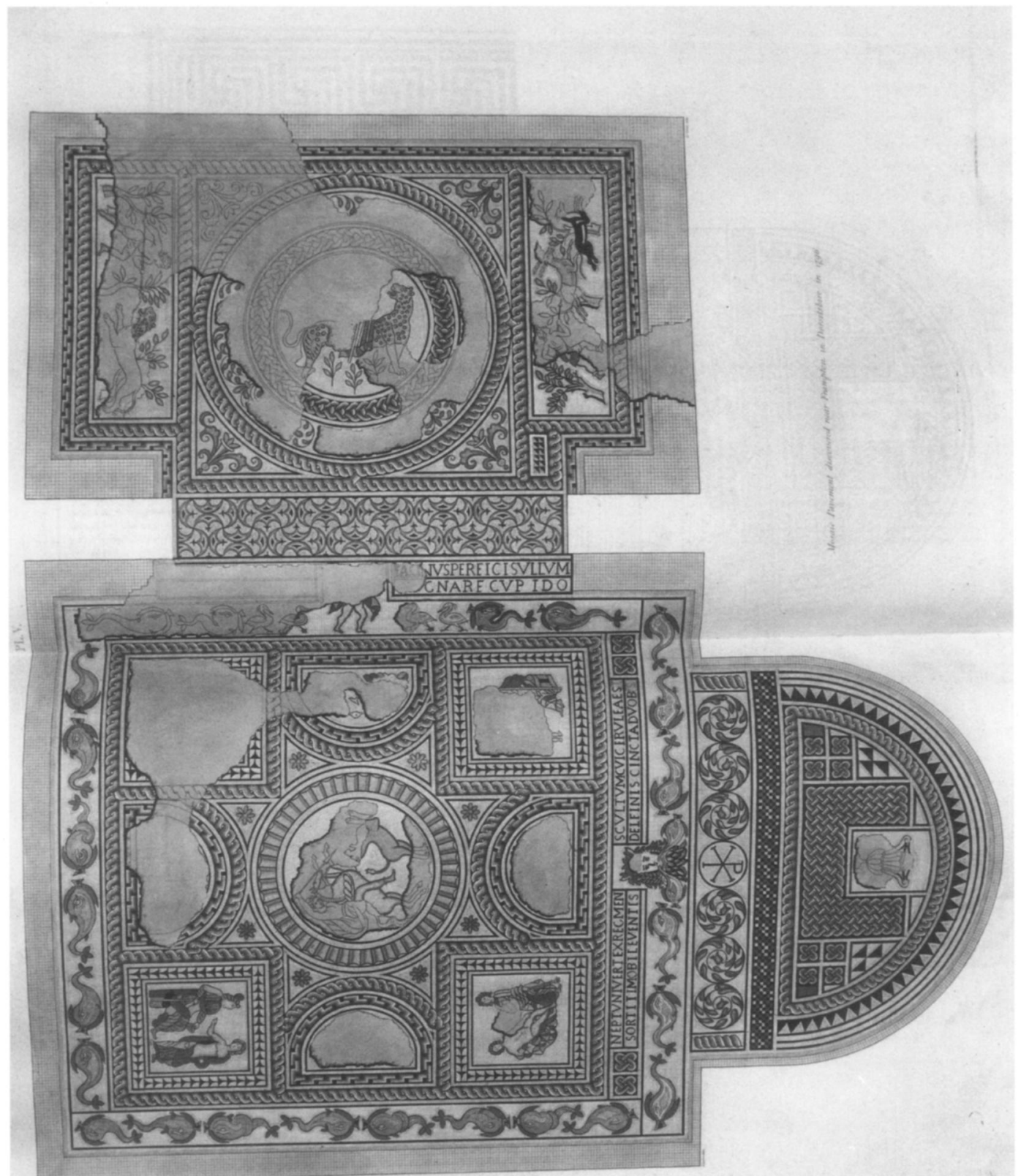


here was hierarchical, involving concealed spaces and indirect lines of access. The mosaics were designed to exaggerate the spatial distinctions achieved by the architecture, giving different identities to three discrete spaces: the antechamber, main room, and apse. Several of the images here made considered contrasts, and the overall impression is that these combined to present a dialectical argument.

Recent studies have stressed the different ways in which the mosaics used in grand reception rooms might have been viewed. ${ }^{38}$ Some rooms were laid out around a main decorative panel. In such places the static nature of the arrangement suited a fixed viewpoint, as might have obtained from the dining-couch. In the rooms at Frampton and Hinton St Mary, however, all areas of the floor were closely ornamented, affording little space for dining-room furniture. The designs were arranged to be viewed from a variety of different positions and favoured a processional, dynamic, and climactic use of the space. The uses of these rooms involved something more dramatic than the normal dinner party. The focal point of the scheme of decoration at Frampton was the chord of the apse: the location of the Christian chi-rho. Most panels were orientated to be seen from this point. Anyone walking into the room would have first had to cross a series of upside-down pictures before reaching this vantage point. The pagan images may have been more numerous, but the Christian one was given the most powerful location. Before the overall significance of this arrangement can be assessed, however, it is first necessary to consider the significance of its individual components.

The entrance to the antechamber was achieved from its north side, where the scene of a lion hunt faced the threshold. A companion panel, on the other side of the room, showed a deer in flight from a hunter and his dog. Such hunt scenes were popular in late antique art, and were commonly located at entrances. A famous example of this is the hunt scene set within the peristyle of the villa at Piazza Armerina in Sicily. ${ }^{39}$

Hunting was a popular aristocratic pursuit, given particular emphasis by the emperor Hadrian who saw it as a test of the inner strength and virtus of the individual. ${ }^{40}$ The chase came to be exploited as a metaphor for the quest for understanding. ${ }^{41}$ An example of the use of hunting scenes in an overtly ritual context in fourth-century Britain is provided by the decoration of the silver strainer found hidden in the London Mithraeum. ${ }^{42}$ This object dates to the post-Mithraic use of this temple, at which time the cultic practices incorporated Bacchic references. The theme was also drawn into Christian iconography, where hunting scenes witnessed the struggle that was Christian life. At Hinton St Mary an antithetical contrast has been drawn between the hunted harts found on the borders of the pavement, representing Christian suffering, and the central roundel showing Christian triumph. ${ }^{43}$

Bacchus, the twice-born giver of immortality, occupied the central place within the antechamber. Bacchus was revered in several late antique mystery cults, many of which borrowed on aspects of Dionysiac ritual and belief. In particular he came to be conflated with the Orphic god Zagreus, and in this guise his worship held an important place in dualistic theology. Bacchic scenes and references were particularly popular in the iconography of late antique mosaics in Roman Britain, ${ }^{44}$ although it is not usually possible to establish whether the god was being

38 Witts 2000. It should also be noted that the walls of these rooms might have been as closely decorated as their floors. Since the wall-paintings did not survive we are missing important elements of the iconographic argument.

39 Carandini 1982. The mosaics at Piazza Armerina represent a comparable and broadly contemporary attempt to describe aspects of a belief system through complex allegory.

40 Brilliant 1979, 63.

41 Clement of Alexandria, The Stromata 1.2; Henig 1995, 155-6.

42 Shepherd 1998.

43 Eriksen 1980, 47.

44 Witts 1995. 
invoked by the followers of Orpheus or by other worshippers. ${ }^{45}$ Bacchus was inextricably associated with both the discovery and savage potency of wine. An ivy-leaf scroll, a decorative element with which Bacchus was closely associated, encircled the majestic icon of this ecstatic god. Ivy, like most types of evergreen foliage, provided a symbol of eternal life. The shape of its leaves also encouraged its identification with the heart.

A pelta border separated the floor of the antechamber from the main room beyond. The pelta motif, which can be read as both an axe and a shield, was a symbolic barrier. Its prophylactic use here added emphasis to the separate identity of the space beyond. Architectural remains from other Romano-British sites suggest that the responds between the two chambers would have supported an arched opening. This may have been hung with curtains.

The main room included three elements. The central part of the floor showed the mortal hero Bellerophon slaying the Chimaera from his winged steed Pegasus. ${ }^{46}$ Four mythological couples occupied subsidiary panels towards the corners of the room. A complex outer border included texts and images that contrasted Neptune with Cupid.

The portrayal of Bellerophon can simply be viewed as a heroic quest involving the victory of good over evil, but it also involves a series of more subtle references. The monster - with its lion's front, goat's middle and snake's tail - was spawned by Typhoeus and was therefore heir to the conflict between the Olympians and Titans. In Orphic cosmographies it was the Titans who destroyed and consumed the infant Bacchus, and it was from the ashes of their destruction that the human race was created. ${ }^{47}$ In this way humanity came to preserve a divine spark within hostile matter. So the slaying of this beast can be seen as part of the ongoing contest between the divine and mortal aspects of material existence. The nature of Pegasus is even more suggestive. This steed was the immortal offspring of Neptune and Medusa, born at the source of Ocean. Pegasus like the hippocamp emerging from seas, the flight of the dolphin, and the birth of Venus - offered a powerful symbol of the contrast between earthbound sea and the flight of immortal soul. This particular antithesis, described in a variety of different ways in the other images found in this room, was one of the most important features of the mosaics at Frampton.

This subject also has sexual undertones, as do several other images chosen here. ${ }^{48}$ Bellerophon's quest came about because he had rejected the advances of Queen Sthenoboea, the wife of King Proetus, and was the victim of false accusation. His battle against the Chimaera was both punishment and atonement.

Bellerophon's ability to tame Pegasus and fly to victory over the Chimaera suggests salvation. Corrupt matter was vanquished by this perfect alliance of human virtue and divine ascendance. The subsequent history of this heroic alliance also deserves attention. Bellerophon was destined to fail in his attempt to fly Pegasus onwards to heaven and he spent the rest of his mortal life wandering the earth. Pegasus, however, reached this higher goal and found his place on Mount Olympus. This, then, was a cautionary tale with a moral. The defeat of the Chimaera occupied the middle part of the story, not its end.

45 Features that might distinguish Orphic ideas from Dionysiac ritual include the use of the seasons as a metaphor for the passage through life, the development of the myths of Attis and Adonis to represent the death and renewal of the soul, and an interest in the crime of the Titans (Guthrie 1966, 55, 101, 120; Legge 1964, 136-7).

46 The reconstruction of this scene by Lysons makes the rider female but David Neal's identification of this as Bellerophon riding Pegasus is indisputably correct (see Ling 1997).

47 In Orphic belief every human is possessed of a dual nature: one Titanic (earthly and corrupt) and one Dionysian (Olympian and immortal). Mystical participation in the body of their god involved eucharistic ritual. The strongly dualistic ideas of Orphism were shared with those of Neoplatonists and contributed to the Christian Platonism of Origen and Clement (Guthrie 1966, 156-7).

48 As pointed out by Scott 2000 following Black 1986 . On the wider importance of sexual symbolism in the symposium see Pellizer 1990, and for the ways in which this influenced the choice of images deployed in late antique mosaic pavements see Muth 1998. 
The representation of Bellerophon in association with Christian motifs occurs only in Britain, where it was also found in the decoration at Hinton St Mary. ${ }^{49}$ The scene was also shown in mosaics in the villa at Lullingstone in Kent. Although these pre-dated the famous house church found at this site, recent speculation holds that the mosaics showing Bellerophon included cryptic Christian references. ${ }^{50} \mathrm{~A}$ suggestive inscription also accompanied the depiction of Bellerophon found in the so-called Palace of Theoderic at Ravenna. ${ }^{51}$

Figurative scenes occupied the corners of the chamber. Two of these were viewed from the chord of the apse, with the other pair facing in the opposite direction. One of the scenes showed a diademed goddess, with a torch pointing down - the symbol of death - and a reclining youth, either dead or asleep. This might have been intended as Selene with Endymion, but it is more probable that the youth was Adonis and the goddess Venus. ${ }^{52}$ In another panel a male figure was shown seated on a rock wearing a Phrygian cap, tunic and trousers and holding a staff and panpipe. The man was shown looking at a standing female figure. The male figure has generally been identified as Attis, the consort of the mother-goddess Cybele. In which case the female figure is probably the nymph Sagaritis with whom he fell in love. Alternatively, but less convincingly, the scene might illustrate Paris and Oenone. ${ }^{53}$ The stories of both Adonis and Attis described human mortality in the context of the soul's subordination to its sexuality. These scenes also testify to the relationship between man and god, and to the divine regenerative powers of the mother-goddess. ${ }^{54}$ Hippolytus describes how these particular contrasts were exploited in Gnostic allegory, ${ }^{55}$ which usage probably derived from Orphic antecedents, as discussed further below.

The third panel showed a seated female, fully draped but with bare feet and holding a long staff. A smaller figure, of which only the bare feet had survived later damage, stood to one side. Henig has suggested that this might illustrate the children of Jason and Medea bringing poisoned gifts to Creusa. ${ }^{56}$ The smaller figure might alternatively have been a Cupid, in which case the female figure might be identified with Venus. There are arrangements showing Venus and Cupid found in mosaics illustrating Aion that provide some parallels for this configuration. ${ }^{57}$ The fourth panel did not survive.

A series of four D-shaped panels set between these four mythological scenes had been destroyed before Lysons made his drawings, although a fish-tail and head can tentatively be made out in one surviving fragment. This suggests that the missing panels featured aquatic motifs. These were perhaps references to matter, the corporeal nature of human existence within which the spirit had been trapped, and were deployed to provide a contrast to the references to the soul found in the four figurative panels described above.

Rosettes were used to fill the gaps between the different scenes. Like the pomegranates featured

49 Toynbee 1964b; Eriksen 1980; Scott 2000. Huskinson 1974, following Brandenburg 1968, is sceptical about the identification of a Christian Bellerophon. Painter 1971, 171, presents the opposite case. An Orphic Bellerophon is, certainly, a possibility. The message of this heroic myth fits closely with the ideas of Orphic dualism. An early association of Bellerophon with Bacchic mythological representations can be seen in fourth-century B.C. mosaics at Olynthus (Dunbabin 1999, 8).

50 Henig 1997.

51 Beeson 1996.

52 There are similarities between both the images involved in the representation of Adonis and Endymion and the ways in which those images might have been understood. Koortbojian 1995 offers some useful parallels for the use of this imagery in funerary contexts, although he proposes a somewhat different interpretation of its significance.

53 Witts 2001, 14.

54 The continuing influence of the story of Adonis and Aphrodite (Venus) in the Christian period is suggested in the writings of Procopius of Gaza (see Friedländer 1939).

55 Hippolytus, Refutation of all Heresies 5.2.

56 Henig 2002.

57 Dunbabin 1999, 166-70. 
in other pavements at Frampton and Hinton St Mary, these are likely to have represented life immortal: red flowers were blood surrogates and a suitable graveside offering. ${ }^{58}$ The celebration of the rites of Adonis also famously involved the Rosalia: the festival of roses.

Two panels of Latin text were set into the mosaic pavement. One of these accompanied the mask of a figure identified by the text as Neptune set facing the apse; the other served as a caption to the small winged figure of Cupid located just inside the entrance from the antechamber. Dolphins were shown emerging from the mouth of Neptune, ${ }^{59}$ and formed a border linking the two panels of text. ${ }^{60}$ Before reaching the figure of Cupid, at the far end of the room, the final pairs of dolphins were replaced by sea birds.

The panels of text formed a verse, apparently in catalectic anapaestic dimeters. ${ }^{61}$ The surviving part of the text accompanying Cupid can be reconstructed to read '[NEC MU]NUS PERFICIS ULLUM | [SI DI]GNARE CUPIDO'. This translates as 'and you do not perform any service, if you deem it fit, Cupid'. The lines placed either side of Neptune read 'NEPTUNI VERTEX REG[I]MEN |SORTITI MOBILE VENTIS | SCUL[P]TUM CUI C[A]ERULEA [EST] | DELFINIS CINCTA DUOB[US]', which suggests the translation 'the head of Neptune allotted the domain stirred by the winds whose dark blue figure is flanked by two dolphins'. ${ }^{62}$

In Bacchic iconography the swimming dolphin symbolised the journey of the human soul, and for this reason dolphins were often shown on sarcophagi. ${ }^{63}$ This usage was later also adopted by the Christian Church and even occurs on Pictish stones. Dolphins were commonly shown on Romano-British mosaics, especially in association with canthari. ${ }^{64}$ This particular association derived from Bacchic usage. If the human soul was intended here, as seems probable, then it is shown voyaging between Neptune and Cupid. The verse places these two immortals in contrast, with Neptune at the source of the soul's existence but Cupid, the more potent of the two, as its destiny. This therefore appears to be an allegorical reference to the ascent of the human soul. To the authors of the mosaic, the sea (Neptune) may have represented the bounds of dark matter from which life was fashioned. The wind was instead identified with the genesis of the human soul, which was at risk of being drawn down by the vortex of mortal forces. ${ }^{65}$ This brings to mind a Gnostic prayer, quoted by Hippolytus, where the soul was described as being 'encircled ... within aqueous form'. This particular antithesis, the victory of Cupid over Neptune, perhaps represented the desired victory of soaring hermaphroditic spirit over mortality. ${ }^{66}$

Finally our attention can turn to the decoration of the apse, the innermost part of this room. The floors here, like those of the main chamber, were designed to be viewed from the chord of the apse. The chi-rho, the main feature that suggests a Christian component to the soteriological interpretations proposed in the design of the Frampton pavements, occupied this focal point. This symbol was placed directly opposite the mask of Neptune. It formed the central medallion in an

58 Ferguson 1970, 144 and 238.

59 This mask actually shows a greater resemblance to Oceanus. Claw-like excrescences emerge like antlers from the sides of the head, and no trident was illustrated. The distinction between Oceanus and Neptune was not taken seriously here.

60 It is significant that the two panels of text were placed in front of the arches that divided this room into three separate spaces. Texts at such locations serve apotropaic and prophylactic functions.

61 Henig 1986a; RIB 2448.8 .

62 RIB 2448.8. See Henig 1986a, 163, for a similar but more liberal translation.

63 Ferguson 1970, 144.

64 Johnston 1987.

65 Hippolytus, Refutation of all Heresies 5.2, uses a very similar metaphor to this. He describes the whirling eddies of water that could draw the soul down into matter or lift it up towards the spark of divine life in his attempt to summarise the dualistic beliefs of the Sethians. This analogy was also found in the Paraphrase of Shem, one of the texts found at Nag Hammadi (Codex VII 1,1.32-2.5), which described the soul trapped in matter as akin to wind in waters.

66 There are parallels for this imagery in the writing of Hippolytus, Refutation of all Heresies 5.9, who describes hermaphroditic Eros as representing the innocent soul in Gnostic thinking. 
ivy-leaf scroll that formed a series of six further circular motifs. Since the chi-rho monogram was a Christianised version of the solar symbol, it is just possible that these seven spheres hinted at the planetary bodies recognised in ancient cosmographies: a reminder of the cosmos through which the soul must pass in ascending to the seventh heaven.

One of the most important clues to our understanding of the way in which the mosaics at Frampton may have been used is given by the large cantharus that occupied the place of honour at the centre of the apse. The apse itself was a powerful architectural feature. It represented a gateway to some other place, a sacred frame located beneath a heavenly dome. ${ }^{67}$ This was an important place within the decorative scheme.

The cantharus was essentially a symbol of conviviality: the chalice where wine and water could be mixed as the host entertained his guests. ${ }^{68}$ In the Greek tradition unmixed wine was a dangerous substance akin to fire, and very much the property of the gods. ${ }^{69}$ The rituals attached to the mixing of wine and water, in which the irrational powers of divine forces were tempered through admixture, made the cantharus into a potent symbol. Its use in Roman iconography suggested immortality and was closely associated with the rites of Bacchus. The cantharus was widely deployed on Romano-British mosaic floors, and was frequently found in association with other Bacchic features. The significance of the symbol appears to have been widely appreciated within Britain. ${ }^{70}$

By the middle of the fourth century the cantharus - along with dolphins, vine-scrolls, and cupids - had passed from Bacchic to Christian iconography, as is shown by the use of these motifs in the decoration of the mausoleum of Santa Costanza c. A.D. 350. This Christian appropriation of the cantharus seems likely to have reflected its identification with the Eucharist. ${ }^{71}$ This image may, therefore, have symbolised the mixing of water and wine that played a central part in the celebration of the Eucharist. ${ }^{72}$ The image of the cantharus was situated to the rear of the apse, with the foreground occupied by a guilloche border. This might arguably have defined a ritual area of purity around the location of a principal altar. ${ }^{73} \mathrm{We}$ know from the Gospel of Philip that fourth-century Gnostic communities used a Eucharistic chalice containing wine and water to represent the Holy Spirit. ${ }^{74}$ The Acts of Thomas, which were probably written in the early third century, also describe a ritual Eucharist involving a mingled cup of wine and bread, within the context of baptismal celebration. ${ }^{75}$ These sources refer to practice in the eastern Mediterranean and are not necessarily relevant to contemporary practice in the North-West provinces. There is also, however, independent evidence to suggest that some form of Christian Eucharist was practised in fourth-century Britain. Painter has shown that dedicatory inscriptions found on some of the items in the Water Newton treasure, a hoard of silver liturgical plate found within Durobrivae, adopt a wording that suggests their use in pre-baptism mass. ${ }^{76}$ This evidence does not prove that the image of the cantharus found at Frampton was understood to represent the Holy Spirit, but it establishes a context in which such an understanding might have been obtained.

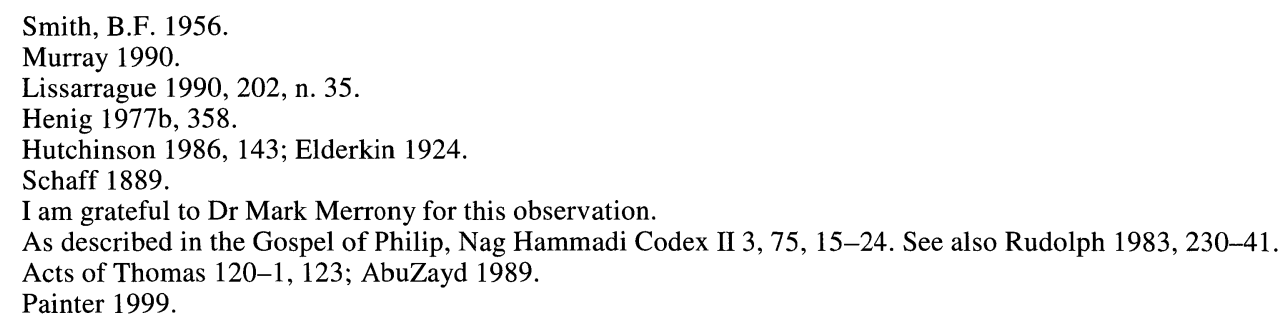


The mosaic designs at Frampton appear to have been laid out to describe a form of quest. ${ }^{77}$ This was the implied premise of the hunt scenes that marked the entrance to the room and was made explicit in the subject of the Bellerophon medallion. The architecture of the room, in which boundaries and partly concealed images regulated an ascent through different realms, would have reinforced this sense of narrative progression. ${ }^{78}$ The purpose of this quest was evidently a victory over death, as promised in various references to the eternal soul. ${ }^{79}$ The design of these mosaics alluded to the accomplishment of eternal life that obtained from a synthesis of contrasting elements.

This quest was of a particular type based, it would appear, on dualistic belief. Such concepts were expressed in a series of antithetical contrasts. The most important of these were those drawn between ethereal spirit (Pegasus-Cupid) and the chains of matter (as represented in references to Neptune and the oceans). Other significant contrasts included those drawn between gods and mortals, and between the sexes.

This dualistic message was reinforced and made specific to Christian teaching by the placement of the chi-rho facing the mask of Neptune at the focal point of the room. This is the feature that best establishes the Gnostic identity of the rituals conducted here. A key element of Gnostic and Orphic worship was the concept that the spirit was held captive in hostile matter, and that salvation involved liberating the soul from mortal chains. This salvation was the accomplishment of a higher mystical knowledge (gnosis). Followers of the cult had to master secrets and sacraments that revealed to them the soul's way out of the world, opening a path through the different spheres of existence. ${ }^{80}$ The arrangement of the mosaics here, in which a proper understanding of the overall scheme can only be appreciated from the privileged location at the chord of the apse, presents a suitable hierarchy of revelation.

The tripartite nature of the decorative scheme deserves further attention. Several Gnostic sects acknowledged three primal principles. ${ }^{81}$ In his description of this tripartite division of the Gnostic universe, Hippolytus recounts how the human spirit was caught between a darkness below, sometimes described as a formidable water, and a light above. This spirit was conceived of as a luminous spark of divinity that had been caught and trapped in matter by the violence of wind on water. ${ }^{82}$ This awareness of the 'three-in-oneness' of existence, which borrowed from Orphic ideas, inspired the use of antithetical contrasts as a means of achieving the ideal of synthesis. This synthesis was ritualised in the mixing of water and wine in the Eucharist, a miracle of transubstantiation that could only be achieved by passing through Christ.

The division of space at Frampton might therefore be read as an attempt to represent this division of existence into its three essential components (FIG. 3). Different Gnostic cosmographies provide somewhat different descriptions of how these three elements should be conceived. In the Valentinian doctrines of Ptolemy described by Irenaeus, for example, differences can be defined between matter, soul, and spirit (pneuma) ${ }^{83}$ In this cosmographic representation the human race

\footnotetext{
77 Perring 2003.

78 It would have been easy to arrange this room axially, with a terminal apse placed opposite a central entrance. This is the more normal arrangement in domestic reception rooms. The room was instead designed in such a way that three separate lines of sight and movement were required to take the visitor from the entrance to the apse.

79 e.g. Bacchus, Pegasus and Bellorophon, Adonis, Attis, the dolphins, the vine-leaf scrolls, the chi-rho, and the cantharus.

80 Jonas 1958,45

81 Rudolph 1983, 90.

82 Hippolytus, Refutation of all Heresies 5.14.

83 For a detailed discussion of these aspects of the Valentinian system see Williams 1999, 17. A more general account of Gnostic approaches to the tripartite division of spirit, soul, and body is found in Rudolph 1983, 91-2.
} 


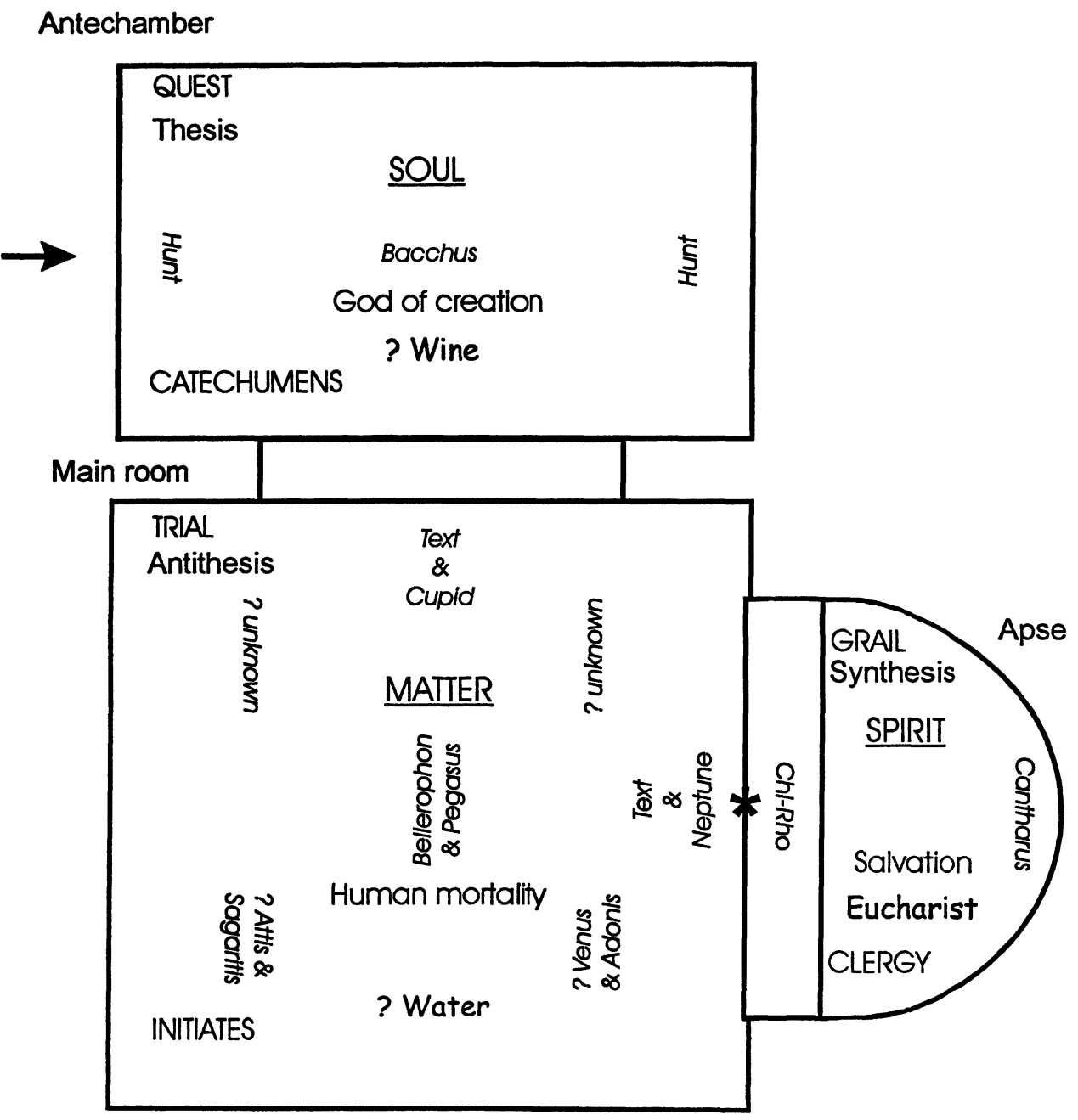

FIG. 3. Some of the concepts represented within the mosaic illustrated as FIG. 2.

took its soul from the demiurge (the known god responsible for the creation of the world) and its flesh from matter. The spirit, the perfect state of existence to which body and soul aspired, instead derived from a female generative power, although in other contexts the spirit was seen as the hermaphroditic product of reconciliation between the division of sexes. There is no particular reason to identify the Frampton pavements as Valentinian, indeed many features of Valentinian theology find no representation here, but it is possible that the dialectic expressed here built on these conceptual distinctions.

If this were the case, the antechamber can best be identified as the place of the soul at its beginning, ruled over by the demiurgic god of creation, here personified as Bacchus. The main room was instead the place of matter and was dedicated to the captive mortal soul in its current state, seeking release. The third space of the apse was reserved for the spirit and for the elect who, 
through their knowledge (gnosis) of Christ and the celebration of his secret rites, had achieved the necessary synthesis of sensual and material (the Gnostic pneumatic). This spatial dialectic is also described in the ritual of the Eucharist, where wine and water become one. It is possible to equate the outer room with the divine potency of wine and unreason (Bacchus), the main chamber with the mortal substance of water (Neptune), and the apse with their mixing in achieving the alchemic synthesis represented by the Holy Spirit (cantharus). ${ }^{84}$ This proposed reconstruction establishes a clear narrative, with the first chamber representing mankind's origins in divine creation, the second referring to the present state of imperfect existence within the shadow of death, and the third looking forward to eventual redemption and release.

The spatial hierarchy both reflects on and lends itself to the rituals that attended the Eucharist. As Peter Brown has observed, 'access to the Eucharist involved a series of visible acts of separation and adhesion' ${ }^{85}$ The rituals assumed a hierarchy in which the bishops and clergy came first, ahead of the faithful (segregated according to their state of grace), and those uninitiated. The division of these rooms into different chambers, separated one from the other by arches where curtains are likely to have hung, would have facilitated the separation of the clergy in the apse, from initiates within the main room, and catechumens in the antechamber. ${ }^{86}$

The Eucharist itself was but a means of representing an even more profound truth. It has been described as a mythic ritualisation of the cycle of life, death, resurrection, and ascension, where earthly substances were transmuted into divine ones and people were similarly transformed ${ }^{87}$ The mosaics may, therefore, have described the path to eternal life, and these rooms represented the ultimate ascent of privilege. It is reasonable to conclude that the goal of the quest described on the floor of the villa at Frampton was symbolised by the Eucharistic chalice, which here took on the attributes of a holy grail. Eternal life - the release of spirit - was the reward of this synthesis between soul and matter, divine and mortal, wine and water.

\section{THE OTHER PAVEMENTS AT FRAMPTON}

So far this paper has concentrated on the evidence of only one of the groups of mosaics found at Frampton. This leaves open the question as to whether any of the other pavements here were designed with aspects of Gnostic-Christian ritual in mind. Just as the main room lends itself to a dialectical interpretation, so it is possible to suggest that the whole house incorporated such distinctions. The fact that three separate areas were decorated with figurative mosaics might point in this direction. It is unfortunate that we know so little of the plan of the buildings, and cannot therefore reconstruct the architectural context within which these decorated spaces functioned. Parallels can, however, be drawn with other sites. Several Romano-British villas were designed with three main reception areas, involving a bath-house located at one end of the house (usually

84 The image of the chalice framed by an apse was used to represent the Eucharistic host in later church architecture, as illustrated by the design of the tabernacle of Santa Maria Maggiore at Florence (now in the Art Institute of Chicago). This motif can perhaps be traced from the hanging chalice-shaped lamps used in Eucharistic liturgy in Byzantine Syria, as shown on the silver pater from Stûmâ (Mango 1986). This may also have been the model for the mosque lamp, framed within the apse of the mihrab, that provides a focal point for Islamic prayer and is taken to represent the light of the prophet (Flood 1999). I am grateful to Rana Mikati for her observations on this.

85 Brown 1998, 40.

86 As suggested by Esmonde Cleary 1989, 125. The meal of the Eucharist can be viewed as an extension of the Roman convivium or symposium (Slofstra 1995, 89), the rituals of which had long been imbued with philsophical and religious significance (see references in note 8). The use of such rooms for worship does not preclude their use as dining-rooms. The typical setting for worship in the late antique house was in the context of the communal meal in the patron's main dining-room (White 2000, 709).

87 Jung 1979, 314. 
the northern or western end), a central audience chamber, and a reception room with a southerly or easterly aspect at the other end of the house. ${ }^{88}$

This tripartite division of reception space can therefore be explained in functional terms but it also lent itself admirably to the needs of Gnostic ritual. In the Gospel of Philip, one of the tractates found at Nag Hammadi, different rituals are alluded to in the context of the sacred architecture of Jerusalem. ${ }^{89}$ According to this text the sanctuary at Jerusalem included three buildings: that to the west was for baptism ('The Holy'), that to the south served the rites of redemption ('The Holy of Holy'), and that to the east was the place of the bridal chamber ('The Holy of the Holies').

If Gnostics had worshiped at Frampton, then their rituals would have included baptism, the celebration of the Eucharist, and perhaps the ceremony of the bridal chamber. ${ }^{90}$ It is, therefore, legitimate to look for evidence of such uses in the architecture and iconography of the site. The most obvious place to locate the rites of baptism would be in a bath-house. Just as dining-rooms could be reconfigured to provide a setting for the celebration of the Eucharist, so plunge baths were easy to convert to the needs of baptism. ${ }^{91}$ Elsewhere I have speculated that the monumental fourth-century cold plunge baths added to the villas at Lufton and Dewlish might have been given this unusual architectural emphasis because of their use as baptisteries. ${ }^{92}$ The octagonal form of these cold baths is particularly suggestive, given the significance attached to octagonal church baptisteries. ${ }^{93}$ The inspiration for baptisteries of this type is likely to have derived from funerary architecture, since the baptistery was a place where the old life gave way to the new in a ritual death leading to re-birth in Christ. According to St Ambrose the octagonal form symbolised the resurrection that took place on the eighth day. It therefore made sense to draw on the architecture of mortality in the location and design of such rooms.

As we have already mentioned, baths were usually located at the northern and western sides of the house. This practice was undoubtedly influenced by the fact that such rooms had little need of daylight. A place at the setting of the sun was, however, also appropriate for ritualised death. In the early baptismal rite candidates are reported to have faced west to renounce the devil and turned east to give themselves to Christ. ${ }^{94}$

Although no baths were found in the villa at Frampton, the room at the north-west end of the house was appropriately located for use in the baptism or annointment of converts to the faith. This association with both mortality and the waters of ritual ablution would have been reinforced by the images here, which focused on aquatic themes. The central bust illustrated Neptune. This was surrounded by heads of four Nereids, or winds, and panels containing dolphins (FIG. 4). Borders of stylised waves were placed to the top and bottom of the pavement. The aquatic emphasis was reinforced by the use of light blue tesserae to form the surround, in place of the white/buff tesserae that framed all of the other mosaics at Frampton.

88 Perring 2002, 140-3. Examples, of different date and form that follow this model, include the Villa of the Mysteries at Pompeii and the fourth-century villa at Piazza Armerina in Sicily. The decorations in the end-rooms of both houses attest to an interest in Bacchic cults. It is not suggested that identical cosmographic concerns inspired this common architecture, but it seems likely that these houses may have hosted domestic rituals influenced by Bacchic and perhaps Orphic rites.

89 Nag Hammadi Codex II 3.

90 Rudolph 1983, 226-47.

91 Private baths were used in Christian baptism (as Rogers 1903,314), but the impact of such use on the architecture of fourth-century bath-houses has received little attention (although see Thomas 1981, 221-5).

92 Perring 2002, 175-7. Both villas also contained mosaics of the same stylistic school ('Durnovarian') as those at Hinton St Mary and Frampton. Rossiter 2002, 628, has, however, pointed out that ornate bath-houses were used as places where guests could be entertained in Late Antiquity, and that this alone might explain the architectural emphasis given to octagonal plunge baths. The functions are not mutually exclusive.

93 As, for example, that built by St Ambrose outside Santa Tecla, Milan in A.D. 375/85 (Roberti 1984, 115).

94 Cyril of Jerusalem, Mystagogic catechesis 1.4; Ambrose, On Mysteries 7. 


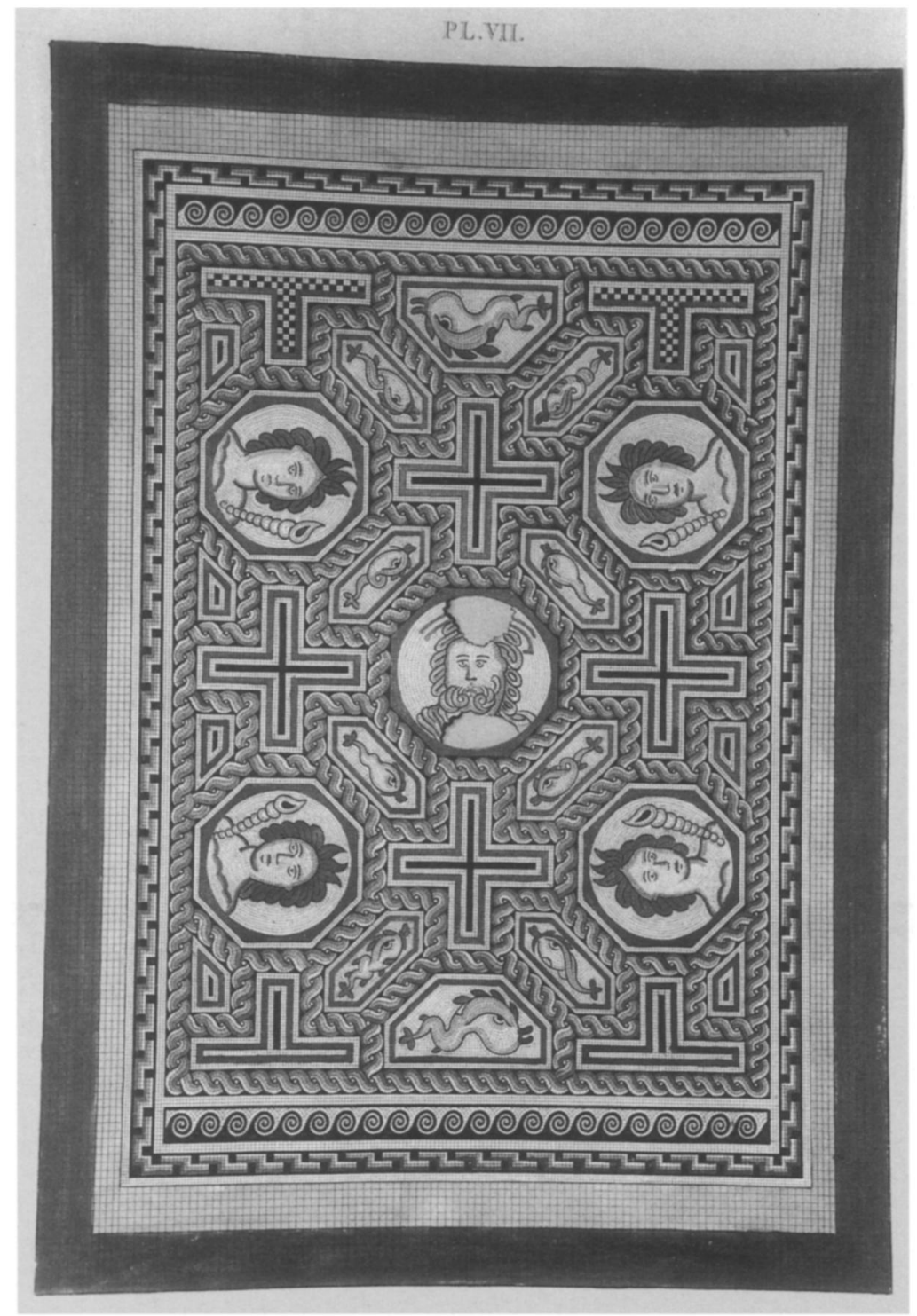

FIG. 4. The Neptune mosaic at Frampton (from a coloured engraving by S. Lysons).

It is also tempting to suggest that the easternmost room of the Frampton villa provided a setting for something akin to the Valentinian mystic rites of the bridal chamber, as referred to by Irenaeus. ${ }^{95}$ The mosaics here were perhaps suited to such use (FIG. 5). A small panel of hounds

95 These rites seem likely to have involved some form of symbolic union of male and female, in achieving a unity of the soul transcending sexual division (Rudolph 1983, 245). Unfortunately the details of how this might have been accomplished are unknown, leaving ample scope to the imagination. 


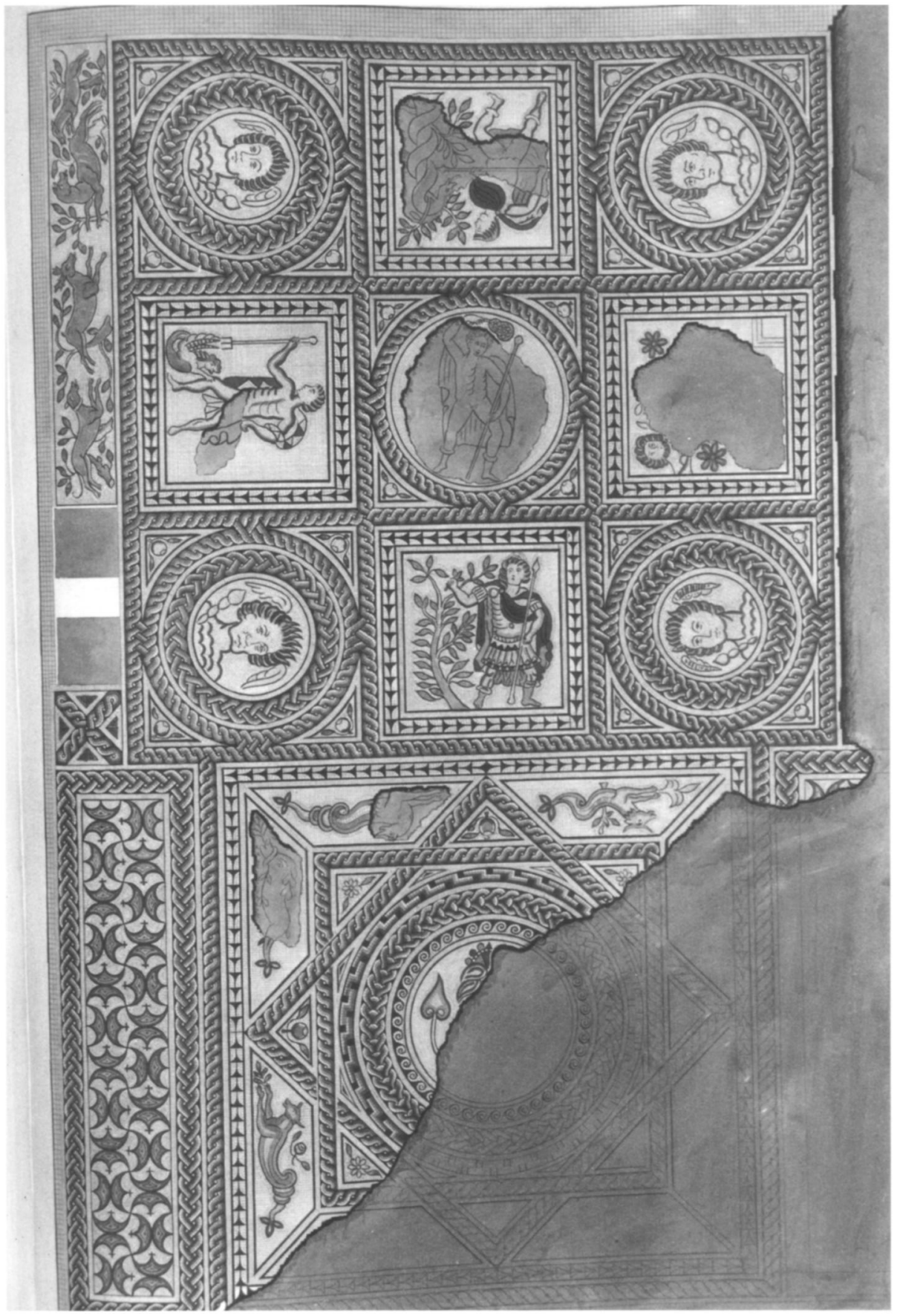

FIG. 5. The Venus and Bacchus mosaic at Frampton (from a coloured engraving by S. Lysons). 
chasing deer marked the entrance to the room. Beyond lay a square mosaic formed of nine separate panels. A central circular medallion may have contained the standing figure of Bacchus, although only fragments of his staff or thrysus and a bunch of grapes survived. Similar circular medallions in the four corners of the design were occupied by busts of the winds. Pomegranates filled spandrels at the corners of these portraits. The other four panels illustrated a series of heroic feats. The first of these has been identified as showing Cadmus slaying the dragon-offspring of Mars, whilst the second portrays Aeneas plucking the golden bough before descending to the Underworld. ${ }^{96}$ The third panel may illustrate Perseus overcoming the sea-monster, although, since the figure holds a trident instead of the more usual scimitar, it might instead have been a clean-shaven version of Neptune. ${ }^{97}$ The fourth panel was badly damaged, but contained a bearded figure in one corner looking out onto a scene that incorporated at least two flowers. It has been suggested that this might be King Lycomedes, witnessing the discovery of Achilles on Skyros. ${ }^{98}$ All four scenes might, therefore, have been drawn from stories found in Ovid's Metamorphoses. ${ }^{99}$ The second mosaic in this bi-partite room was laid out around a central circular medallion containing a female bust wearing a diadem. This was perhaps intended as a representation of the goddess Venus. Small panels around this medallion contained flowers and pomegranates, and an outer border was decorated with hippocamps (sea-centaurs) and similar sea monsters with cows' heads.

Bacchus therefore ruled the first part of the room but the inner chamber was the realm of Venus, perhaps suggesting the subordination of the powers of the male demiurge to the greater perfection of the mother goddess. The emphasis given to the defeat of dragons and serpents witnessed in two of the panels set alongside Bacchus (those supposed to show Cadmus and Perseus) is intriguing. Serpents were important to several Gnostic communities, especially the Ophites and Naassenes. ${ }^{100}$ The serpent was closely associated with the tree of life, and the other two mythological scenes shown on this floor may also have alluded to the garden of paradise. The golden bough, which Aeneas picked from the sacred grove in order to buy entrance to the Underworld, was a symbol of wisdom and initiation: these were the properties of the tree of knowledge. ${ }^{101}$ The damaged fourth scene in this group appears to show a garden, as suggested by the presence of two rosettes flanking the tableau. If the identification of the bearded figure as Lycomedes is correct, as suggested by Cosh, then the mosaic shows Achilles being discovered in the garden of the palace of Skyros. ${ }^{102}$ This room perhaps describes man's encounter with wisdom, which led also to the discovery of his sexuality, in the garden of creation. If this speculative reconstruction is correct, then this is further evidence of the Gnostic character of the mosaics here.

\section{OTHER SOURCES OF EVIDENCE}

These interpretations of the Frampton mosaics are necessarily conjectural but provide a coherent account of what might otherwise seem a rather disparate group of images. The next question to be addressed is whether or not the interpretations proposed here can be applied more widely. The site is certainly unusual, but there is a significant body of evidence from other Romano-British sites to suggest that there was wider engagement with some of the arguments represented here.

Many Romano-British mosaics were laid in the fourth century, in particular in the period A.D.

96 These identifications are based on those of Barrett 1977 and Henig 1984.

97 Beeson 2000.

98 Cosh 1996.

99 See Henig 2002, 81-2 for further comment on these and other literary allusions found in Romano-British mosaics.

100 Rudolph 1983, 145.

101 The tree of life also figures importantly on the pavement at Hinton St Mary.

102 Cosh 1996. 
320-360, and the art of this period shows an unusual preoccupation with complex mythological scenes. ${ }^{103}$ The subjects were not, however, drawn randomly from a wide range of subjects. The most popular individual deities were Jupiter (in his various guises), Bacchus, Neptune/Oceanus, Orpheus, and Venus (and related mother goddesses). The scenes portrayed concentrated on the relationships between divine and mortal, male and female, life and death, and select features from heroic quests. ${ }^{104}$ This repertoire may have been biased towards subjects addressed in the writings of Virgil and Ovid.

The pavements at Lullingstone in Kent share several characteristics with those found at Frampton and Hinton St Mary, although they are stylistically very different. The villa at Lullingstone is best known for its fourth-century wall-paintings, which featured the Christian chi-rho monogram as well as a series of figures with their arms uplifted in prayer (orantes). ${ }^{105}$ Archaeological dating suggests that the mosaics at Lullingstone were laid a couple of decades before the paintings were executed, but it is almost certain that they were in use at the same time. ${ }^{106}$ The central panel of the main mosaic was dominated by another depiction of Bellerophon slaying the Chimaera. As at Frampton, dolphins encircled the scene, whilst bivalves drew exaggerated attention to the fact that Pegasus was born at the sources of Oceanus. ${ }^{107}$ This emphasis lends support to the suggestion that the main theme of this allegorical representation was that of the soul on its voyage heavenwards. Here too, as in the treatment of Neptune and Cupid at Frampton, the important contrast was between generation in mortal ocean and the apotheosis of perfect spirit. The central panel was accompanied by busts of the four seasons in a possible reference to the cycle of life. ${ }^{108}$

A second mosaic panel was set in an apse of the same room. Here Europa, with one foot trailing in the dark sea, was carried into the pale sky on the back of Jupiter in the guise of a bull. Following convention two Cupids were in attendance: one to offer encouragement and the other to hinder the process. The scene was accompanied by a couplet that described how jealous Juno would have had even greater justification in resorting to the help of Aeolus had she seen the bull, in reference to the story described in Virgil's Aeneid. ${ }^{109}$ It is also possible that the text contained cryptographic Christian references. ${ }^{110}$ The Aeneid was popular with Romano-British patrons, and scenes from this story also appear on the pavements at Low Ham. ${ }^{111}$ In this particular couplet we are reminded of the recourse made by a jealous god to the powers of wind and sea in an attempt to stop the pilgrim from reaching his or her goal. This theme is suited, although not uniquely so, to Gnostic interpretation.

Looking beyond the evidence of Lullingstone, it has also been suggested that the impressive fourth-century mosaics featuring the lyre-playing Orpheus, surrounded by concentric circles of

103 Smith, D.J. 1977. Witts 2001 has noted similarities between the range of mythological subjects preferred in Romano-British mosaics and those from sites such as Antioch. Common features included an emphasis on Bacchic scenes and illustrations drawn from Ovid. This argument can be extended to other sites in the eastern Mediterranean that shared an unusual passion for mythological scenes. Contrasting fashions are likely to have been influenced by local theological differences. It has been noted that different religious tendencies can appear in fairly close regions, although it is not clear to what extent this was the consequence of differences within communities or between them (Chuvin 1990, 45).

104 Muth 1998 has drawn similar conclusions from the study of the late antique mosaics of North Africa and Spain. These scenes focus on moments of tragic loss, death, and grief and give emphasis to the relationships between male and female, and between gods and mortals. The over-riding concern was with the nature of the soul.

105 Meates 1979.

106 Coin evidence suggests that the pavement discussed here was laid early in the $360 \mathrm{~s}$, and was therefore contemporary with the floor at Frampton. See Henig 2002, 108.

107 Smith, D.J. 1977, 111.

108 Scott 2000, 145-54.

109 Barrett 1978, 311.

110 RIB 2448.6; Henig 1997.

111 See Henig 2002, 82. 
animals and birds, may have been crypto-Christian. ${ }^{12}$ Stupperich has already identified elements in one such mosaic at Cirencester that hint at Gnostic influence. ${ }^{113}$ This took the form of a serpentlike figure, possibly Abraxas or Naos, accompanying Orpheus. An important Orpheus pavement was found in a triconch room in the aisled building of the villa at Littlecote Park in Wiltshire (dated c. A.D. 360). This consisted of two chambers separated by a wide arched opening, with apses on all three remaining sides of the inner chamber. A mosaic of Orpheus surrounded by animals was laid on the floor, and incorporated a variety of other decorative elements: including the figures of other deities, canthari, and vine scrolls. Walters has suggested that these scenes described a syncretic Orphic cult, involving also the god Apollo. ${ }^{114}$ The illustration of a cantharus flanked by sea-beasts is certainly suggestive, as are the references to Bacchus and Orpheus.

A fourth-century Bacchus pavement in the reception room of an aisled building at Thruxton in Hampshire included a dedication to 'Qvintvs Natalivs Natalinvs et Bodeni'. 115 Henig and Soffe suggest that this collective dedication is likely to represent the activities of a religious cult or guild. ${ }^{116}$ Natalinus with his Roman tria nomina would have been the patron and the Bodeni dependants who shared in the religious practices. ${ }^{117}$ Several other Romano-British pavements include Bacchic, Orphic, and Neoplatonic references, although this is not the place for an exhaustive treatment of the evidence. ${ }^{118}$ In all cases these images might have supported Gnostic interpretation, but we cannot prove that they did so. The main point is that, although the mosaics at Frampton and Hinton St Mary were unusual in their direct use of Christian iconography, they can be set within a broader contemporary tradition that expressed proximate concerns and aspirations. The ideas that they expressed were not alien to the interests of other Romano-British patrons.

Iconographic representations of a similar nature were employed in the decoration of some of the silver and pewter vessels buried in fourth-century hoards. ${ }^{119}$ This is most vividly illustrated in the Mildenhall treasure, and particularly by the magnificent silver dish that formed the centre-piece of this service. This vessel was adorned with a central mask of Neptune or Oceanus, surrounded by two friezes of figures. The inner frieze included Tritons, Nereids, and hippocamps - some with snake-like rear quarters - in a marine thiasos (a band of cult worshippers and followers). The outer border included Bacchus with attendant revellers in another thiasos. This piece was unashamedly Bacchic, as were some other items from the hoard. The treasure also included undeniably Christian symbols and inscriptions, and has been dated to the period A.D. 330-60. ${ }^{120}$

\footnotetext{
112 Toynbee 1968; Scott 2000, 159-60.

113 Stupperich 1980, 300.

114 Walters 1984.

115 RIB 2448.9.

116 Henig and Soffe 1993.

117 For alternative interpretations see Black 1987, 81 and Birley 1993, 239.

118 Hutchinson 1986 provides a corpus of mosaics that include Bacchic imagery whilst the survey by Scott 2000 places fourth-century Romano-British pavements in their social context. Other pavements that might be included in a more detailed survey of dualistic and Neoplatonic influences include those at Brading, Withington, and Bignor (Henig 1986a, 153; Henig 2002, 107).

119 For a summary of Christian elements see Watts 1991,27. Many of the hoards with Christian and Bacchic elements were buried in East Anglia, see Petts 2003. This is an area where figurative mosaic pavements are poorly represented. The archaeological evidence indicates that different approaches were taken to the display of belief systems in different territories. The Iceni (East Anglia) invested in the portable treasures used in cult practice, whilst the Durotriges (Dorset) spent on the buildings and mosaics that provided a setting for such practice. It is not clear whether or not this reflects on local differences in liturgical practice, and in the belief systems involved, but this seems likely. This in turn suggests that Romano-British communities were actively engaged in elaborating the theological arguments involved. It would therefore be a mistake to expect to find a perfect match between the Gnostic heresies described in the sources (none of which claims direct knowledge of theological developments in Britain) and the cognate beliefs represented in the Romano-British art.

120 Hutchinson 1986, 16-17; Painter 1977.
} 
Scholars have struggled to account for the presence of both Christian and Bacchic elements in this and other contemporary hoards. This has been a particular problem in the study of the Thetford treasure, where the Bacchic features also involved invocations to the Latin god Faunus: 'Dei Fau[ni] Medugeni (mead begotten)' ${ }^{121}$ The treasure included a series of silver spoons. Two of these were decorated with confident Bacchic designs: one showed a Triton, dolphin, and rosette; another showed the panther. But other spoons in this treasure were illustrated with motifs that appear Christian. These included fishes and palms, and an inscription 'silviola vivas' which was followed by a Greek cross. ${ }^{122}$ Some of the names of the celebrants found engraved on individual items are also of Christian type. The argument over whether this was a pagan or Christian treasure, or an odd amalgam of the two, is resolved if it is seen to represent a coherently Gnostic assemblage drawing on the same intellectual traditions represented in the mosaics that have been described above.

These silver hoards were dominated by objects designed for use in religious ritual and especially by items of a type that might be used in the celebration of the Eucharist. ${ }^{123}$ In addition to the vessels, cups, and plates used in the celebration of the mass, strainers could be used to separate the bread from the wine, and decorated spoons were used to administer the Eucharist. Picks and prongs might have been used to put communion bread into the wine. ${ }^{124}$ It is thought unlikely that such Eucharistic practices were commonly adopted by the orthodox Church in the West, although they can be identified in the East. ${ }^{125}$ As has already been mentioned, however, Painter's study of the Water Newton treasure indicates that this had been used in the mass that accompanied baptism. ${ }^{126}$ This particular hoard makes no direct reference to Bacchic ideas or images, and could have been assembled by a more orthodox Christian community. The implication, however, is that a fair proportion of the late antique plate found in Romano-British hoards had been used in church liturgy. In some cases the vessels and instruments designed for use in this supposed Eucharistic practice incorporated images that borrowed heavily from Bacchic, presumably Orphic, models. This evidence therefore lends support to the arguments built from the evidence of the mosaics.

Several individual finds provide supporting evidence for the diffusion of dualistic, although not necessarily Christian, ideas in Roman Britain. For instance, gemstones depicting Cupid burning a butterfly (Psyche) with a torch describe the torment of the spirit. ${ }^{127}$ An engagement with Orphism is also implied by a series of hairpins, dating from as early as the late first century, designed to show a hand holding pomegranates or eggs. ${ }^{128}$ It is difficult to know how much weight to attach to this sort of evidence, without knowing more about the context in which such objects were used.

\section{THE HISTORICAL CONTEXT}

Several of the iconographic ideas found at Frampton first appeared in Britain in the course of the early second century. One of the earliest pavements that lends itself to dualistic interpretation is the splendid Cupid and dolphin mosaic from the villa at Fishbourne in Sussex, laid sometime after A.D. 160. ${ }^{129}$ This use of Cupid riding the dolphin to represent the voyage of the soul held such

121 Johns 1986.

122 Watts 1991, 150-2.

123 de Bhaldraithe 1991; Toynbee 1953, 22; Painter 1999.

124 Their use as toothpicks is also attested.

125 Watts 1991, 157; Frend 1984-5, 149.

126 Painter 1999.

127 Henig $1977 \mathrm{~b}$.

128 Arthur 1977, 370-1.

129 Cunliffe 1971, 163-5; Rudkin 1981, 8. 
broad currency that it could have been used to represent any one of the many soteriological belief systems then in favour. In this case, however, the use of hippocamps and canthari to frame the central panel locates the mosaic within the Bacchic tradition. A near contemporary pavement from Verulamium showed the head of Neptune or Ocean surrounded by four canthari. ${ }^{130}$ A pavement from Colchester, dated $c$. A.D. 150-175, showed wrestling Cupids in a central panel with marine creatures placed in lateral semicircles. ${ }^{131}$ Other mosaics of this period from London and Verulamium were also decorated with dolphins and canthari.

This selective survey of evidence shows that the Frampton mosaics were heir to a longerestablished interest in the nature and character of the immortal soul, which drew on symbols and allegories borrowed from the worship of Bacchus. This interest was, at least in part, inspired by dualistic beliefs and incorporated ideas taken from the teachings of Orpheus and his followers. It is possible to suggest that these ideas exercised a significant influence on changing fashions in Romano-British domestic art in the period shortly after $c$. A.D. 150. Similar arguments can be advanced for other parts of the Roman world, and the ideas at issue may also be relevant to our understanding of contemporary changes in some other spheres of cultural behaviour. ${ }^{132}$

This leaves open the question of whether or not the theological structures within which these ideas were expressed were in any sense Christian or Gnostic at such an early date. Christianity is certainly likely to have won British adherents during the course of the second century. The earliest references to the religion reaching Britain are those of Tertullian and Origen, dating to the late second and early third centuries. Whilst these authors may have been guilty of poetic embellishment, ${ }^{133}$ it would be surprising if the new religion did not already have adherents within the province. ${ }^{134}$ Gnostics also represented an important strand of thought within the heterodox community that characterised the early years of the Christian mission, such that by $c$. A.D. 180 Irenaeus, Bishop of Lyon, felt it necessary to publish his anti-heretical attacks against this particular school of thought. ${ }^{135}$ If there were significant numbers of such heretics in Lyon at this time, then it is perfectly credible - given the strong political and cultural links that existed between Gaul and Britain - that they would also have been present in Roman Britain. This remains, however, a matter of speculation. The sources are silent.

The earliest evidence we have for a more explicitly Christian element in the iconography dates to the fourth century. Indeed, most of the art described here was a product of the middle of that century. It appeared a generation or so after the Edict of Milan and the Council of Nicaea had respectively accommodated and regulated Christian worship. This was a period when the Roman state had not firmly allied itself to the orthodox cause, but when Christianity was rapidly becoming the ideology of power. At this time it was still possible for powerful patrons to affiliate themselves to a variety of different belief systems within the context of an ascendant Christianity. We can only speculate as to whether the more overt use of Christian references was the product of a new-found confidence in the outward display of long-established private religion, or represented a new syncretic development in which earlier soteriological movements incorporated novel arguments within evolving theologies.

The interpretations of the Romano-British iconography advanced here suggest an unusually explicit adoption of Bacchic-Orphic ideas by Christian worshippers. This is implied both by the

130 Wheeler and Wheeler 1936, 146.

131 Crummy 1980; Henig 1986b.

132 A relationship might exist between changing burial practices (including details of burial rite, orientation, and location) and the diffusion of the soteriological ideas described here.

133 The view of Frend 1968.

134 Toynbee 1953.

135 Irenaeus, Against Heresies. 
mosaics at Frampton and Hinton St Mary, and by the composition of fourth-century silver hoards. This accommodation of pagan features was perhaps at the expense of Judaic ones. ${ }^{136}$ Frampton was also a long way away from the schools of Gnostic thought based at Antioch and Alexandria. If Gnostic teaching had inspired the mosaics described here, then these images offer an important new source of information about how such ideas were conceived and articulated in the Latin West.

The retrospective, eclectic, syncretic, and Hellenistic form of Orphic-Gnostic-Christianity suggested by the evidence implies that the ideas were not being developed as part of any challenge to the existing status quo but instead conformed to the existing beliefs and prejudices of a Romano-British élite society. ${ }^{137}$ The emphasis that Gnostic ritual gave to knowledge and initiation served to protect, not challenge, the existing basis of social power. This was a mystery religion accessible only to educated classes with the leisure to engage in its arcane secrets. If the inscription at Thruxton is any guide, the villa-owning élite retained a commanding role as the principal patrons and leading figures of the religious communities formed around such worship.

The Gnostics also rejected the structures of bishops and clergy, and relied on the 'wisdom of the brotherhood ... the spiritual fellowship of those united in communion' ${ }^{138}$ These beliefs and structures were positively antithetical to the institutional Church. There are several reasons why such ideologies might have had a particular appeal to property-owning classes in the Romano-British countryside. This was a province where urban institutions remained comparatively underdeveloped, and where social power appears to have been exercised from aristocratic country houses. ${ }^{139}$

Elsewhere in the Roman Empire the institutional Church played a crucial role in sustaining urban life in Late Antiquity. Through an established pattern of urban bishoprics the Church redirected rural surplus into the cities and developed the ceremonies and rituals that gave focus to urban life. ${ }^{140}$ Christianity made power urban, and by the same token it held in check an aristocratic tendency to retreat to the countryside. If, as is suggested here, Gnosticism had obtained a hold on a significant faction of élite society in Britain, then this is likely to have both reflected on and contributed to the underdevelopment of ecclesiastical and urban institutions. It is perhaps relevant that the cities that sent bishops to the Council of Arles in A.D. 314 - York, London, and perhaps Lincoln ${ }^{141}$ — were those most closely aligned to the official imperial project.

The last period when pagan and heretical ideas were easily tolerated, however, was under the emperor Julian who died in A.D. 363. It seems unlikely to be coincidental that so much of the evidence described here, including the mosaics at Frampton and Lullingstone, can be dated to this period. Thereafter Gnostic views were soon suppressed. In A.D. 371 the emperor Valentinian forbade the public worship of Manichaeans. ${ }^{142}$ His successor Theodosius took a more aggressively orthodox stance, and in the course of the 380 s promulgated at least fifteen anti-heretical edicts. ${ }^{143}$ Fines were imposed on heretical bishops, religious meetings were proscribed, and the emperor confiscated buildings used for illegal worship. At this time Britain was ruled by Maximus, tolerated as a co-emperor by Theodosius in the period A.D. 384-7. Maximus was allegedly a fervent Christian and given to confiscating the property of great landowners. ${ }^{144}$ It was under his rule that leaders of the Priscillianist heretics in Spain were executed in an escalation of anti-heretical

136 Several studies, as summarised by Russel 1994, 78, have placed the historical origins of Gnosticism within the Jewish tradition, whilst the importance of Orphism has generally been understated. This reflects the biases in our sources.

137 This view of Gnosticism as 'conformist' rather than 'dissenting' is detailed by Williams 1999, 101-3.

138 Apocalypse of Peter, Nag Hammadi Codex VII 3; Pagels 1979, 106.

139 Perring 2002, 218-19.

140 Harries 1992, 90.

141 Thomas 1981, 197.

142 Chuvin 1990, 50-1, Frend 1968.

143 Theodosian Code 1.16. tit. v. leg. 6-23.

144 Chuvin 1990, 58. 
repression. ${ }^{145}$ We have no sources for the political and religious history of Britain to tell us how widespread heresy might have been, or how vigorously it was punished. What is clear, however, is that the political circumstances had moved decisively against the kinds of worship implied by the evidence described here.

Archaeological evidence illustrates a series of important changes in the period commencing around A.D. 370; some of these might possibly witness the effects of these political changes. In the first place the fashion for commissioning expensive mosaics illustrating mythological scenes came to a fairly abrupt end. This was accompanied by a series of radical changes in the nature of domestic architecture. Reception activities were differently configured — if not entirely dispensed with - at a series of villas. ${ }^{146}$ These architectural changes preceded the collapse of the Roman administration at the end of the fourth century and cannot simply be explained as a product of that event. In several instances mosaic pavements were built over or damaged, and in some instances carefully destroyed. ${ }^{147}$ It is important to note that in many cases the mosaics were not simply left to fall into disrepair but were positively made redundant as room functions were changed and floors destroyed. These architectural changes tell us that patterns of life had changed, and previously important ideas about social display had sometimes been abandoned.

Something of this nature might have happened at Frampton. The areas of damage recorded by Lysons do not seem irregular and random, but appear to have involved the selective destruction of certain figurative scenes. ${ }^{148}$ The elements removed from the floor included most of the cantharus that dominated the apse and four panels in the main room that might have contained aquatic scenes. This selective destruction might have been a consequence of the re-evaluation of the meaning of the images that were presented.

It is also possible that a series of features and objects associated with Christian baptism were decommissioned or destroyed at about this time. Several circular lead tanks decorated with Christian motifs were discarded and damaged in the course of the late fourth century. ${ }^{149}$ One of these tanks, found at Walesby, included a small figurative scene that Thomas has convincingly argued illustrates the baptism of a female initiate, or competens. ${ }^{150}$ It is therefore reasonable to conclude that these were portable fonts used for baptism, although there are different opinions on the exact nature of the ritual involved. ${ }^{151}$ Most of the tanks had been badly damaged prior to their burial in antiquity; some had been cut up into pieces, and several had been thrown into wells.

Petts has shown that this was part of a wider practice of votive deposition influenced by earlier tradition. ${ }^{152}$ What is not so clear is whether such deposits were associated with ongoing cultic

145 Sulpicius Severus, Hist. Sacra 1.2. A recent study of the possible archaeological sources for a study of Priscillianism in Spain by Bowes 2001 offers interesting parallels for the study of heretical belief in Britain. Bowes observes that 'two of the more prominent fears associated with Priscillianism were Christian practices in the countryside and unsupervised worship in the home'. The architecture of house-churches found on villa estates in Spain supports the idea that villa-churches maintained a considerable degree of autonomy from episcopal and parochial hierarchies. These churches were designed to meet the needs of both the patron and the wider rural community.

146 Perring 2002, 44-5.

147 A recently excavated example is that of the town-house at 1 Poultry in the City of London where mosaics were neatly excised from the floor in the late fourth century (Rowsome 2000, 47).

148 It might alternatively be argued that the areas of damage reflect on the more fragile nature of the tesserae used for finer decorative detail in the missing panels. It is not at all clear, however, why this might have been the case and it seems unlikely.

149 Watts 1991, 158-73; Guy 1981; Petts 2003. Most of these tanks were found in East Anglia and the East Midlands. The pattern of their distribution is similar to that of the contemporary hoards described above.

150 Thomas 1981, 222-3.

151 Frend 1992, 124, following Thomas 1981, is more comfortable with the idea that these were fonts for baptism by affusion, where water would have been poured over the head of an initiate standing within the tank, whilst Watts 1991, 169, prefers the proposal of West 1976, 78-9, that they were for other ritual ablutions such as the washing of feet (pedilavium).

152 Petts 2003. I am grateful to David Petts for drawing my attention to this issue and letting me see a copy of his paper ahead of publication. 
practice, in which their burial was part of a ritual offering of adherence, or whether this was the respectful sacrifice and exorcism of objects that retained potency but were now ideologically redundant. One possibility is that in some instances cult items were cut up, mangled, or dismembered before burial not because they were being prepared for melting down or as an act of mindless vandalism, but because this was part of a traditional response to neutralising the magic of rejected gods. This better explains why these hoards were never recovered, and why their distribution is consistent with other forms of ritual deposition. A parallel can perhaps be drawn with the cult items associated with the temple of Mithras in London. These icons and treasures were ritually 'killed' and buried, some in watery contexts, when this building was converted to a different form of worship in the early fourth century. ${ }^{153}$

Another instance of the possible late fourth-century redundancy of an early fourth-century Christian baptistery might be represented by the evidence from the villa at Chedworth. ${ }^{154} \mathrm{~A}$ spring-fed octagonal basin set in an open-fronted building to one side of this villa had been decorated with Christian symbols, including the familiar chi-rho. Although this structure is usually described as a nymphaeum, the association is an assumed one, and the structure might alternatively, or subsequently, have served as a place of baptism. The octagonal basis was, however, dismantled in a late phase of the use of the villa.

There is, therefore, a body of evidence witnessing the late fourth-century decommissioning of features and finds associated with the Christianity of the middle part of the century. This is broadly contemporary with the more widespread evidence for the dereliction of some Romano-British villas. Explanatory frameworks have tended to see this as part of the more widespread political and military crisis attendant on the 'barbarian conspiracy' of A.D. 367, described by the historian Ammianus Marcellinus. ${ }^{155}$ This concerted barbarian attack, perhaps allied to unrest within the province, is supposed to have resulted in a near complete breakdown of social and political order in Britain, and provides a context that might arguably have contributed to an anti-Christian paganism. This is the argument of Frend who sees this as a turning-point in the fortunes of the province. ${ }^{156} \mathrm{He}$ suggests that the longer-term effects of the disturbances undermined the development of the institutions of Christianity, and uses this thesis in order to account for the subsequent failure of Britain to preserve an episcopal Church.

An alternative model can now be proposed. If the Christianity adopted in some parts of Roman Britain had followed Gnostic rather than orthodox theology, then such practice is likely to have been suppressed in the period A.D. 370-390. Suppression would have involved the prevention of heretical baptism, might have involved the confiscation of properties used as places of Gnostic worship, and could eventually have led to the ritualised destruction and ceremonial burial of church plate. ${ }^{157}$ These hoards might have been buried for much the same reasons as the Nag Hammadi texts were buried in Egypt in the late fourth century. ${ }^{158}$ I do not wish to suggest that we can somehow attribute all of Britain's fourth-century woes to the social consequences of religious repression, but the possibility that this was one of the factors involved in the changes of the period deserves attention. It is also possible to speculate on the repercussions that such a dispute may

153 Perring 1991, 115-16. Henig 1984 has suggested that, following this event, the London Mithraeum may have become a place of Bacchic worship. Perhaps this Bacchus served an Orphic-Gnostic-Christian community.

154 Fox 1887; Thomas 1981, 220.

155 Ammianus 38.8.1 (barbarica conspiratione); Frere 1987, 339-45.

156 Frend 1992.

157 I do not suggest that all of the hoards and votive deposits were buried in the immediate aftermath of a single episode of brutal suppression. This was clearly not the case. There is, however, a possible causal relationship between changing regimes of ideological control, the practice and commemoration of particular forms of baptismal initiation, and the eventual decommissioning of items used in such liturgical practice.

158 Rudolph 1983, 43. 
have had on the subsequent political history of Britain. The disaffection or dispossession of parts of Roman Britain's landed aristocracy is one possible outcome, and this in turn might have contributed to the eventual rejection of the Roman administration $c$. A.D. 409 as described by Zosimus. ${ }^{159}$ It is equally interesting to speculate on the ways in which Gnostic ideas might have influenced subsequent Christian belief and iconography in Britain. ${ }^{160}$ But these speculations cannot easily be put to the test and take us beyond the evidence that is in front of us.

\section{ACKNOWLEDGEMENTS}

I am grateful to Steve Roskams and two anonymous referees for their comments on an earlier draft of this paper.

Department of Archaeology, University of York dp19@york.ac.uk

\section{BIBLIOGRAPHY}

AbuZayd, S. 1989: 'The acts of Thomas and the unity of the dualistic world in the Syrian Orient', ARAM $1.2,217-52$

Arthur, P. 1977: 'Eggs and pomegranates. An example of symbolism in Roman Britain', in J. Munby and M. Henig (eds), Roman Life and Art in Britain, British Archaeological Reports 41(ii), Oxford, 367-74

Barrett, A.A. 1977: 'A Virgilian scene from the Frampton Roman villa, Dorset', Antiq. Journal 57, 312-13 Barrett, A.A. 1978: 'Literary classics in Roman Britain', Britannia 9, 307-14

Beeson, A. 1996: 'Pegasus the Wonder Horse and his portrayal on Romano-British mosaics', Mosaic 23, $18-23$

Beeson, A. 2000: 'The Frampton Trident Bearer', Mosaic 27, 4-7

Bhaldraithe, E. de 1991: 'Strainers and other instruments in early Church ritual', in D. Watts, Christians and Pagans in Roman Britain, London \& New York, 231-3

Birley, A.R. 1993: Review of R.G. Collingwood and R.P. Wright, RIB. Vol. 2. Instrumentum Domesticum (Personal Belongings and the Like), JRS 83, 237-9

Black, E.W. 1986: 'Christian and pagan hopes of salvation in Romano-British mosaics', in M. Henig and A. King (eds), Pagan Gods and Shrines of the Roman Empire, Oxford University School of Archaeology Monograph 8, Oxford, 147-58

Black, E.W. 1987: The Roman Villas of South East England, British Archaeological Reports 171, Oxford

Bowersock, G.W. 1990: Hellenism in Late Antiquity, Cambridge

Bowes, K. 2001: “ "Nec sedere in villam". Villa-churches, rural piety, and the Priscillianist controversy', in

T.S. Burns and J.W. Eadie (eds), Urban Centres and Rural Contexts in Late Antiquity, Michigan, 323-48

Brandenburg, H. 1968: 'Bellerophon Christianus?', Römische Quartalschrift 63, 49-86

Brandenburg, H. 1969: 'Christussymbole in frühchristlichen Bodenmosaiken', Römische Quartalschrift $64,75-138$

Brilliant, R. 1979: 'Mythology', in K. Weizmann (ed.), Age of Spirituality: Late Antique and Early Christian Art, Third to Seventh Century, New York, 129-98

Brown, P. 1992: Power and Persuasion in Late Antiquity, Madison, Wisconsin

Brown, P. 1998: Late Antiquity, Cambridge, Mass.

159 Zosimus 6.5.

160 There is nothing to suggest that Gnostic worship survived into fifth-century Britain, but echoes of dissent might have contributed to the intellectual formation of Pelagius and his followers. Since the mosaics in the main room at Frampton described a form of grail quest, it is also possible to draw speculative connections between the allegories represented here and those subsequently incorporated in Arthurian legend (e.g. Weston 1907). 
Carandini, A. 1982: Filosofiana: the Villa of Piazza Armerina, Palermo

Chuvin, P. 1990: A Chronicle of the Last Pagans, Cambridge, Mass.

Cosh, S.R. 1996: ‘A possible Achilles at Frampton', Mosaic 23, 13-15

Crummy, P. 1980: 'Mosaics from Middleborough, Colchester', Mosaic 2, 5-9

Cunliffe, B.W. 1971: Excavations at Fishbourne 1961-69 Vol. 1, Leeds

Dickmann, J.-A. 1997: 'The peristyle and the transformation of domestic space in Hellenistic Pompeii', in R. Laurence and A. Wallace-Hadrill (eds), Domestic Space in the Roman World: Pompeii and Beyond, JRA Suppl. Ser. 22, Michigan, 121-36

Dunbabin, K.M.D. 1999: Mosaics of the Greek and Roman World, Cambridge

Eisler, R. 1925: Orphisch-dionysische Mysteriengedanken in der christlichen Antike, Liepzig \& Berlin

Elderkin, G.W. 1924: 'The continuity of pagan and eucharistic symbolism', in Kantharos: Studies in Dionysiac and Kindred Cult, Princeton, 41-7

Elsner, J. 1998: Imperial Rome and Christian Triumph, Oxford

Eriksen, R.T. 1980: 'Syncretic symbolism and the Christian Roman mosaic at Hinton St Mary: a closer reading', Proceedings of the Dorset Natural History and Archaeological Society 102, 43-8

Esmonde-Cleary, A.S. 1989: The Ending of Roman Britain, London

Farrar, R.A.H. 1956: 'The "Frampton Villa”, Maiden Newton', Proceedings of the Dorset Natural History and Archaeological Society 78, 81-3

Ferguson, J. 1970: The Religions of the Roman Empire, London

Flood, F.B. 1999: 'Light in stone. The commemoration of the Prophet in Umayyad architecture', in J. Jones (ed.), Bayt al-Maqdis. Jerusalem and Early Islam, Oxford, 311-59

Fox, G.E. 1887: 'The Roman Villa at Chedworth, Gloucestershire', Archaeological Journal 44, 322-36

Frend, W.H.C. 1968: 'The Christianization of Roman Britain', in M.W. Barley and R.P.C. Hanson (eds), Christianity in Britain, 300-700, Leicester, 46-9

Frend, W.H.C. 1984-5: 'Syrian parallels to the Water Newton treasure?', Jahrbuch für Antike und Christentum 27-8, 146-50

Frend, W.H.C. 1992: 'Pagans, Christians, and "the Barbarian Conspiracy" of A.D. 367 in Roman Britain', Britannia 23, 121-31

Frere, S.S. 1987: Britannia: a History of Roman Britain (3rd edn), London

Friedländer, P. 1939: Spätantiker Gemäldezyklus in Gaza, Vatican

Friedman, J.B. 2000: Orpheus in the Middle Ages, New York

Guthrie, W.K.C. 1966: Orpheus and Greek Religion: a Study of the Orphic Movement, New York

Guy, C.J. 1981: 'Roman circular lead tanks in Britain', Britannia 12, 271-6

Harries, J. 1992: 'Christianity and the city in Gaul', in J. Rich (ed.), The City in Late Antiquity, London, 77-98

Henig, M. 1977a: 'Roman gemstones: figuretype and adaptation', in J. Munby and M. Henig (eds), Roman Life and Art in Britain, British Archaeological Reports 41(ii), Oxford, 341-6

Henig, M. 1977b: 'Death and the maiden: funerary symbolism in daily life', in J. Munby and M. Henig (eds), Roman Life and Art in Britain, British Archaeological Reports 41(ii), Oxford, 347-66

Henig, M. 1984: 'James Engleheart's drawing of a mosaic at Frampton, 1794', Proceedings of the Dorset Natural History and Archaeological Society 106, 146

Henig, M. 1986a: “"Ita intellexit numine inductus tuo”: some personal interpretations of deity in Roman religion', in M. Henig and A. King (eds), Pagan Gods and Shrines of the Roman Empire, Oxford University School of Archaeology Monograph 8, Oxford, 159-70

Henig, M. 1986b: 'Late Roman mosaics in Britain, myth and meaning', Mosaic 13, 13-20

Henig, M. 1995: The Art of Roman Britain, London

Henig, M. 1997: 'The Lullingstone mosaic: art, religion and letters in a fourth-century villa', Mosaic 24, 4-7

Henig, M. 2002: The Heirs of King Verica. Culture and Politics in Roman Britain, Stroud

Henig, M., and Soffe, G. 1993: 'The Thruxton Roman villa and its mosaic pavement', Journal of the British Archaeological Association 146, 1-28

Highet, G. 1957: The Classical Tradition, New York

Huskinson, J. 1974: 'Some pagan mythological figures and their significance in early Christian art', Papers British School Rome 42, 68-97

Hutchinson, V. 1986: Bacchus in Roman Britain, British Archaeological Reports 151, Oxford 
Johns, C.M. 1986a: 'Faunus at Thetford: an early Latian deity in late Roman Britain', in M. Henig and A. King (eds), Pagan Gods and Shrines of the Roman Empire, Oxford University School of Archaeology Monograph 8, Oxford, 93-104

Johnson, P. 1983: 'The Ilchester Lindinis Officina', Mosaic 8, 5-8

Johnston, D.E. 1987: 'Dolphins in Romano-British mosaics', Mosaic 14, 18-22

Jonas, H. 1958: Gnostic Religion, Boston

Jones, C.P. 1991: 'Dinner theatre', in W.J. Slater (ed.), Dining in a Classical Context, Ann Arbor, 18598

Jung, C.G. 1979: 'Transformation symbolism in the Mass', in J. Campbell (ed.), Eranos. Papers from the Eranos Yearbooks 2: The Mysteries, New York, 274-336

Koortbojian, M. 1995: Myth, Meaning and Memory on Roman Sarchophagi, London

Legge, F. 1964: Forerunners and Rivals of Christianity, New York

Ling, R. 1997: 'Mosaics in Roman Britain: discoveries and research since 1945', Britannia 28, 259-96

Lissarrague, F. 1990: 'Around the krater: an aspect of banquet imagery', in O. Murray (ed.), Sympotica. A Symposium on the Symposion, Oxford, 196-209

Lysons, S. 1817: Reliquiae Britannico-Romanae iii, London

Mango, M.M. 1986: Silver from Early Byzantium: the Kaper Koraon and Related Treasures, Baltimore

Meates, G.W. 1979: The Lullingstone Roman Villa. 1: The Site, Kent Archaeological Society Monograph 1, Maidstone

Meyer, M.W., and Robinson, J.M. 1981: The Nag Hammadi Library in English (2nd edn), San Francisco

Murray, O. 1990: 'Sympotic history', in O. Murray (ed.), Sympotica. A Symposium on the Symposion, Oxford, 3-13

Muth, S. 1998: Erleben von Raum - Leben im Raum: zur Funktion mythologischer Mosaikbilder in der römisch-kaiserzeitlichen Wohnarchitektur, Heidelberg

Pagels, E. 1979: The Gnostic Gospels, London

Painter, K.S. 1967: 'The Roman site at Hinton St Mary', BM Quarterly 32, 15-31

Painter, K.S. 1971: 'Villas and Christianity in Roman Britain', BM Quarterly 35, 156-75

Painter, K.S. 1977: The Mildenhall Treasure, London

Painter, K.S. 1999: 'The Water Newton silver: votive or liturgical?', Journal of the British Archaeological Association 152, 1-23

Pellizer, E. 1990: 'Outlines of sympotic entertainment', in O. Murray (ed.), Sympotica. A Symposium on the Symposion, Oxford, 177-84

Perring, D. 1991: Roman London, London

Perring, D. 2002: The Roman House in Britain, London

Perring, D. 2003: 'Deconstructing the Frampton pavements: Gnostic dialectic in Roman Britain?', in G. Carr, E. Swift and J. Weekes (eds), TRAC 2002: Proceedings of the Twelfth Annual Theoretical Archaeology Conference, Canterbury 2002, Oxford

Petts, D. 2003: 'Votive hoards in late Roman Britain: pagan or Christian?', in M. Carver (ed.), The Cross Goes North. The Age of Conversion in Northern Europe, AD 300-1300, York, 109-18

Reece, R. 1980: ‘A date for Hinton St Mary?', Mosaic 2, 21-2

Roberti, M.M. 1984: Milano Romana, Milan

Roberts, A., and Donaldson, D. (eds) 1950-1957: The Ante-Nicene Fathers: Translations of the Writings of the Fathers down to AD 325, Grand Rapids

Rogers, C.F. 1903: Baptism and Christian Archaeology, Oxford

Rossi, G.B. de 1867: Roma Sotterranea, Rome

Rossiter, J. 1991: 'Convivium and villa in late antiquity', in W.J. Slater (ed.), Dining in a Classical Context, Ann Arbor, 199-214

Rossiter, J. 2002: 'Houses in Roman Britain', Journal of Roman Archaeology 15, 625-9

Rowsome, P. 2000: Heart of the City: Roman, Medieval and Modern London Revealed by Archaeology at 1 Poultry, London

Rudkin, D. 1981: 'Recent discoveries at Fishbourne Roman palace', Mosaic 4, 8-10

Rudolph, K. 1983: Gnosis: The Nature and History of Gnosticism (transl. R. Wilson), Edinburgh

Russel, J.C. 1994: The Germanization of Early Medieval Christianity. A Sociohistorical Approach to Religious Transformation, New York \& Oxford

Schaff, P. 1889: History of the Christian Church: Ante-Nicene Christianity: AD 100-325, Edinburgh 
Scott, S. 2000: Art and Society in Fourth-Century Britain: Villa Mosaics in Context, Oxford University School of Archaeology Monograph 53, Oxford

Shepherd, J.D. 1998: The Temple of Mithras, London: Excavations by W.F. Grimes and A. Williams at the Walbrook, EH Archaeological Report 12, London

Slofstra, J. 1995: 'The villa in the Roman West: space decoration and ideology', in J. Metzler, M. Millett, N. Roymans and J. Slofstra (eds), Integration in the Early Roman West, Dossier d'Archéologie du Musée National d'Histoire et d'Art 4, Luxembourg, 77-90

Smith, B.F. 1956: Architectural Symbolism of Imperial Rome and the Middle Ages, Princeton

Smith, D.J. 1969: 'The mosaic pavements', in A.L.F. Rivet (ed.), The Roman Villa in Britain, London, $71-125$

Smith, D.J. 1977: 'Mythological figures and scenes in Romano-British mosaics', in J. Munby and M. Henig (eds), Roman Life and Art in Britain, British Archaeological Reports 41(i), Oxford, 105-94

Smith, J.T. 1997: Roman Villas: a Study in Social Structure, London \& New York

Stupperich, R. 1980: 'A reconsideration of some fourth-century British mosaics', Britannia 11, 289-301

Teçusan, M. 1990: 'Logos sympotikos: patterns of the irrational in philosophical drinking: Plato outside the symposium', in O. Murray (ed.), Sympotica. A Symposium on the Symposion, Oxford, 238-60

Thomas, C. 1981: Christianity in Roman Britain to AD 500, London

Toynbee, J.M.C. 1953: 'Christianity in Roman Britain', Journal of the British Archaeological Association 3rd ser. 16, 1-24

Toynbee, J.M.C. 1964a: Art in Britain under the Romans, Oxford

Toynbee, J.M.C. 1964b: 'A new Roman pavement found in Dorset', JRS 54, 7-14

Toynbee, J.M.C. 1968: 'Pagan motifs and practices in Christian art and ritual in Roman Britain', in M.W. Barley and R.P.C. Hanson (eds), Christianity in Britain, 300-700, Leicester, 177-92

Tybout, R.A. 2001: 'Roman wall-painting and social significance', Journal of Roman Archaeology 14, 33-57

Wallace-Hadrill, A. 1988: 'The social structure of the Roman house', Papers British School at Rome 56, 43-97

Walters, B. 1982: 'Fourth-century "Orphic" halls in Britain', Mosaic 7, 23-6

Walters, B. 1984: 'The Orpheus mosaic in Littlecote Park England', Mosaico Ravenna, 433-42

Watts, D. 1991: Christians and Pagans in Roman Britain, London \& New York

West, S. 1976: 'The Romano-British site at Icklingham', East Anglian Archaeology 3, 63-126

Weston, J.L. 1907: 'The Grail and the rites of Adonis', Folk-Lore 18 (reprinted in J. Mathews (ed.), Sources of the Grail, Edinburgh, 1996, 431-48)

Wheeler, R.E.M., and Wheeler, T.V. 1936: Verulamium. A Belgic and Two Roman Cities, Oxford

White, M.L. 2000: 'Architecture: the first five centuries', in P.F. Esler (ed.), The Early Christian World, London \& New York, 693-746

Williams, M.A. 1999: Rethinking Gnosticism, Princeton

Witts, P. 1995: 'Bacchus on Romano-British mosaics', Mosaic 22, 15-19

Witts, P. 2000: 'Mosaics and room function: the evidence from some fourth-century Romano-British villas', Britannia 31, 291-324

Witts, P. 2001: 'Universal messages: iconographic similarity between the mosaics of Antioch and Britain', Mosaic 28, 13-17 